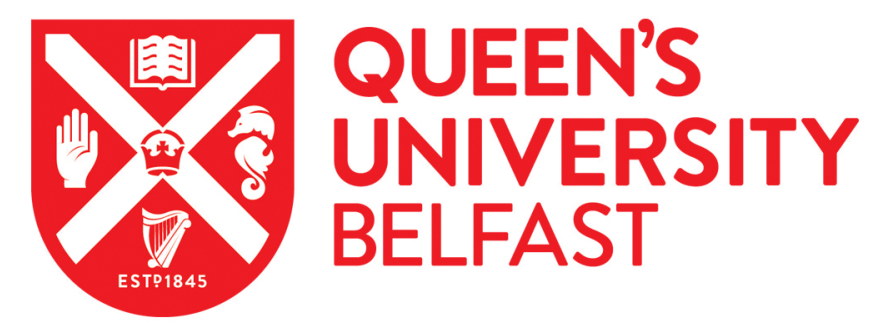

\title{
Historical Pageants and the Medieval Past in Twentieth-Century England
}

Bartie, A., Fleming, L., Freeman, M., Hulme, T., Hutton, A., \& Readman, P. (2018). Historical Pageants and the Medieval Past in Twentieth-Century England. English Historical Review, 133(563), 866-902.

https://doi.org/10.1093/ehr/cey158

\section{Published in:}

English Historical Review

\section{Document Version:}

Peer reviewed version

Queen's University Belfast - Research Portal:

Link to publication record in Queen's University Belfast Research Portal

\section{Publisher rights}

Copyright 2018 Oxford University Press. This work is made available online in accordance with the publisher's policies. Please refer to any applicable terms of use of the publisher.

\section{General rights}

Copyright for the publications made accessible via the Queen's University Belfast Research Portal is retained by the author(s) and / or other copyright owners and it is a condition of accessing these publications that users recognise and abide by the legal requirements associated with these rights.

Take down policy

The Research Portal is Queen's institutional repository that provides access to Queen's research output. Every effort has been made to ensure that content in the Research Portal does not infringe any person's rights, or applicable UK laws. If you discover content in the Research Portal that you believe breaches copyright or violates any law, please contact openaccess@qub.ac.uk. 


\section{Historical Pageants and the Medieval Past in Twentieth-century England ${ }^{1}$}

For much of the twentieth century, historical pageants were one of the most widespread and popular forms of public engagement with the past. Following the success of the first modern historical pageant at Sherborne in Dorset in 1905 (see Figure 1), England succumbed to what contemporaries called 'pageant fever' or 'pageantitis'. ${ }^{2}$ Towns and cities across the country staged historical pageants, involving hundreds or thousands of amateur performers, and watched by sometimes tens of thousands of spectators over several performances. The ubiquity of pageants in Edwardian England is now coming to be appreciated by scholars, not least due to the work of Ayako Yoshino, who has written the only monograph thus far devoted to the topic. ${ }^{3}$ The typical historical pageant contained around ten scenes of local history. It showcased moments at which the history of the particular town had intersected with the larger national story, but also key moments in its medieval history, the latter often including the establishment of a monastery or castle, or the receipt of a royal charter. Historical pageants remained important during the interwar period, when many towns and cities staged them for the first time, notably in the industrial north and midlands of England. ${ }^{4}$ Village, country house and church pageants were also popular, and this was reflected in their frequent appearance in the literature of the time, such as Virginia Woolf's novel Between the

\footnotetext{
${ }^{1}$ The research on which this article is based arises from the Arts and Humanities Research Council-funded project, 'The Redress of the Past: Historical Pageants in Britain 1905-2016' (award number AH/K003887/1). See http://www.historicalpageants.ac.uk/ for further details. ${ }^{2}$ D.S. Ryan, “Pageantitis": Frank Lascelles' 1907 Oxford Historical Pageant, Visual Spectacle and Popular Memory', Visual Culture in Britain, viii (2007), pp. 63-82. ${ }^{3}$ A. Yoshino, Pageant Fever: Local History and Consumerism in Edwardian England (Tokyo, 2011).

${ }^{4}$ T. Hulme, "“A nation of town criers": Civic Publicity and Historical Pageantry in Inter-War Britain', Urban History, xliv (2017), pp. 270-92.
} 
Acts. ${ }^{5}$ In the 1940s and early 1950s there was a revival of historical pageants, largely but by no means exclusively centred on the Festival of Britain (1951) and the coronation of Elizabeth II (1953). This period of pageantry in particular has been less heavily studied by historians, although research on the Festival has pointed to the importance of its engagement, both locally and nationally, with history and tradition. ${ }^{6}$ As Mark Freeman has shown, postwar pageants differed in some respects from their Edwardian precursors, but would certainly have been recognisable to those who had been caught up in the 'pageant fever' of fifty years earlier. $^{7}$

\section{[FIGURE 1 NEAR HERE]}

Pageants were a particular kind of historical drama, which usually had a recognisable episodic structure and an origin within, or at least a clear focus upon, the place which they depicted and in which they were staged. There were, of course, affinities with other traditions of historical performance, not least Shakespeare's history plays, which since their first staging were an important channel of communication of ideas about the past, and an important means of engagement with it. ${ }^{8}$ Notably, excerpts from Shakespeare were often used in pageant scripts, reflecting the medieval setting of many of his plays. ${ }^{9}$ Pageants also drew on more recent influences ranging from the English folk revival to Wagnerian opera, and the costumed depiction of historical characters was a feature of other elements of civic ritual

\footnotetext{
${ }^{5}$ Virginia Woolf, Between the Acts (London, 1941); Victor L. Whitechurch, Murder at the Pageant (London, 1985 [1930]); Clifton Robbins, The Man without a Face (London, 1932); Richmal Crompton, 'The May King', in More William (London, 2015 [1922]). ${ }^{6}$ H. Atkinson, The Festival of Britain: A Land and Its People (London, 2012).

${ }^{7}$ M. Freeman, "Splendid Display; Pompous Spectacle”: Historical Pageants in TwentiethCentury Britain', Social History, xxxviii (2013), pp. 423-55.

${ }^{8}$ D. Goy-Blanquet, Shakespeare's Early History Plays (Oxford, 2003).

${ }^{9}$ One example was the Southampton Quincentenary Pageant of 1947, which began with the trial scene from Act II of Henry V: Programme of the Charter Commemorations Celebrating the Occasion of the Quincentenary of the County Town of Southampton (Southampton, 1947). See H. Cooper, Shakespeare and the Medieval World (London, 2010).
} 
around the turn of the twentieth century, including processions and carnivals. ${ }^{10}$ During the twentieth century itself, historical pageantry evolved alongside a burgeoning enthusiasm for amateur dramatic, operatic and choral societies, which peaked during the mid-century heyday of the 'middlebrow', and which themselves often made substantial contributions to the organisation and personnel of pageants. ${ }^{11}$ These cultural activities were successively influenced by the cinema, radio and television, all of which impinged in different ways on popular understanding of history, and all which affected the representation of the past in historical pageants. Indeed, it has been suggested that the growth of television, in particular, was a key element in the decline of historical pageants and similar spectacles. ${ }^{12}$ Of course, pageants were just one way in which the people of twentieth-century England met with the past: they also encountered it in schoolrooms, in the evolving broadcast media, as readers of textbooks and historical novels, and in many cases as visitors to historical sites such as stately homes and castles. Pageants, however, often lived long in the memories of individuals, and in the collective memories of the communities that staged them. Those involved in pageants often kept souvenirs of their experiences: these included personalised scrapbooks, postcards, books of words, programmes, decorative ceramics, and even ticket stubs. ${ }^{13}$ The public counterpart to such private memorialisation was equally diverse and extensive: aside from monuments and commemorative plaques, houses and other buildings, open spaces, streets

\footnotetext{
${ }^{10}$ R. Judge, 'Merrie England and the Morris 1881-1910', Folklore, 104 (1993), p. 135; M. Dobson, Shakespeare and Amateur Performance: A Cultural History (Cambridge, 2011), 167-8; Yoshino, Pageant Fever, 49-56; D. Georgiou, “'Only a local affair”? Imagining and Enacting Locality though London's Boer War Carnivals', Urban History (published online, 22 Feb. 2017).

${ }^{11}$ See A. Nicoll, English Drama 1900-1930: The Beginnings of the Modern Period, Part I (Cambridge, 2009 [1973]), pp. 87-93.

${ }^{12}$ Freeman, "'Splendid Display", p. 454.

${ }^{13}$ Raphael Tuck and Co., among other firms, produced various series of postcards for individual pageants. See, for example, Oxford Magazine, xxv (1907), pp. 363, 419. For an example of a pageant scrapbook, see 'Sister's Pageant Memories', Warwick Record Office: CR367/39.
} 
and pubs were named after pageants, ${ }^{14}$ and in the case of some public amenities-

Sherborne's pageant gardens for example — were also funded from their proceeds. ${ }^{15}$ On these grounds - as well as for the simple reason of their sheer scale and ubiquity — pageants deserve closer examination.

Pageants involved prominent individuals from the worlds of theatre and of academic and popular history. Leading Edwardian 'pageant-masters' such as Louis Napoleon Parker and Frank Lascelles became synonymous with the form, as did their interwar successors such as Gwen Lally and Matthew Anderson. Lally was responsible for the huge Birmingham pageant in 1938 and Anderson staged various events in England and Scotland, culminating in the Pageant of Ayrshire in 1934. ${ }^{16}$ Other figures took up the reins of pageantry after the Second World War, including flamboyant impresarios such as Lawrence du Garde Peach, the author of several Ladybird books on English history and pageant-master at Nottingham (1949) and elsewhere, as well as notable figures from amateur dramatics such as Cyril Swinson, who produced several pageants in the south-east of England between 1948 and his death in $1963 .{ }^{17}$ These pageant-masters and many others were responsible for the definition

\footnotetext{
${ }^{14}$ There is a Pageant Drive in Sherborne, a Pageant Road in St Albans and a Pageant Place in Framlingham, while the town of Arbroath - a great centre of Scottish pageantry - boasts a pub called 'The Pageant'. One of the more elaborate public memorials was erected in 1914 at Bath, where a very large pageant had been staged five years previously. Here, in the grounds of Sydney Gardens, a replica of the Temple of Minerva, which had formed part of the city's contribution to the 1911 London Festival of Empire, was re-erected to commemorate the pageant, 'a handsome bronze tablet' on the building recording the event for posterity: Bath Chronicle and Weekly Gazette, 20 June 1914, p. 5.

${ }^{15}$ Costing $£ 700$, the Sherborne Pageant Gardens were opened in 1906, being paid for and maintained using the $£ 1872$ profits of the pageant held the previous year: Cecil P. Goodden, The Story of the Sherborne Pageant (Sherborne, 1906), p. 32.

${ }^{16}$ Hulme, "Nation of town criers"”, 12-14; D.S. Ryan, 'Lally, Gwen (1882-1963)', Oxford Dictionary of National Biography (Oxford, 2004): http://www.oxforddnb.com/view/article/59378 (accessed 7 Mar. 2017).

${ }^{17}$ E.D. Mackerness, 'Peach, Lawrence du Garde (1890-1974), Oxford Dictionary of National Biography: http://www.oxforddnb.com/view/article/49367 (accessed 7 Mar. 2017); Lawrence du Garde Peach, King John and Magna Carta (Loughborough, 1969). On Swinson see Freeman, "“Splendid Display", pp. 437-48.
} 
and re-definition of a particular and - for a period of almost sixty years — very successful form of theatrical representation of the past. Moreover, for much of this time pageantry had an academic imprimatur in the form of the involvement or support of prominent historians, not least Charles Oman and G.M. Trevelyan. Oman was an avowed fan of pageantswrote an episode and played Friar Bacon in the Oxford pageant of 1907, and later wrote the preface to the programme of the Harrow Historical Pageant of 1923 — while Trevelyan cowrote and also performed in the Berkhamsted pageant of the previous year, taking the part of Geoffrey Chaucer. ${ }^{18}$ Indeed, as the example of Trevelyan suggests, authors of popular works of history, not least Peach himself and, in the interwar period, Arthur Bryant, were notably enthusiastic participants in pageants and their organisation. Elsewhere, script-writers took advice from academic historians and amateur local antiquarians, and their programmes and books of words often cited a range of primary source material. Pageants, then, are an aspect of the history of theatre, but also of the wider intellectual history of twentieth-century Britain: a form of 'edutainment' avant la lettre. ${ }^{19}$

Much of the existing scholarship on twentieth-century historical pageants has focused on issues of community and identity, at local, national and imperial levels. Pageants and their associated events have been used to draw wider conclusions about contemporaneous understandings of community and the role played by representations of the past in forming and sustaining identities. Yoshino has argued that Edwardian pageant scripts fostered popular imperialism, particularly through allusions to the Roman empire, while Paul Readman has downplayed this aspect in favour of an interpretation centred on 'the local roots of national

\footnotetext{
${ }^{18}$ Charles Oman, Memories of Victorian Oxford and of Some Early Years (London, 1941), chapter 22, esp. pp. 255-6; id., 'In Praise of Pageantry', in The Handbook of the Harrow Historical Pageant (Harrow, 1923), pp. 7-9; M. Moorman, George Macaulay Trevelyan: A Memoir (London, 1980), p. 202.

${ }^{19}$ The Oxford English Dictionary dates the first use of 'edutainment' to 1983.
} 
identity'. ${ }^{20}$ The choice of episodes reflected moments at which the town or city staging the pageant had played an important role in the larger national story, or when a prominent royal figure such as King John or Elizabeth I had visited the place. As Yoshino notes, pageants played an important role in showcasing towns as potential tourist destinations, ${ }^{21}$ but they also worked for the existing local community, being seen as ways of promoting local interest in history and heritage. Civic pride was a common theme of Edwardian pageants, and Freeman has argued that a sense of proud localism was, if anything, even more significant when historical pageants were staged in the mid-twentieth century. ${ }^{22}$ The resilience and adaptability of historical pageants attest to the durability of long-established understandings of community identity, and the mutually supportive relationship that these had with narratives of local and national history: the past remained important to feelings of belonging, in respect of places and institutions. Hence, we argue in this article, the importance of the medieval period across the whole history of twentieth-century pageantry. Pageants told aspects of the national story, and it was in the medieval period that England was thought to have been united and in many senses 'created'. However, if England 'began' in the Middle Ages, this was no less true of the places where pageants were staged, be they towns, cities or villages. Prehistory and the ancient world certainly featured in many pageants, but the foundations of most modern communities were understood to lie firmly in the medieval period. Even in places with a substantial Roman heritage_-Edwardian examples included St Albans (which staged a pageant in 1907) and Colchester (which did so in 1909) — the medieval past was a central element of local community identity, often inscribed in man-made surroundings which, as

\footnotetext{
${ }^{20}$ Yoshino, Pageant Fever, chapters 3-4; P. Readman, 'The Place of the Past in English Culture', Past and Present, clxxxvi (2005), p. 178.

${ }^{21}$ Yoshino, Pageant Fever, chapter 2.

${ }^{22}$ Freeman, "'Splendid Display", pp. 427, 441-3.
} 
Anthony D. Smith has emphasised, can do as much as the natural environment to "locate" a community in its landscape'. ${ }^{23}$

In terms of episodes depicted in pageants, the Middle Ages tended to predominate in the early years of the twentieth century, and remained very important thereafter. At Sherborne, the action began in 705 with St Ealdhelm, the first bishop of Sherborne, and ended with Sir Walter Raleigh's visit to the town in 1593; eight of the eleven episodes were set before $1500 .{ }^{24}$ Other pageants followed a similar trajectory, often beginning in the ancient past and typically ending in the sixteenth or seventeenth centuries, although in some casesOxford's second pageant, in 1912, for example — the content was entirely medieval. ${ }^{25}$ Even where scenes from modern times featured, the emphasis was on the more distant past. Half the episodes at Liverpool in 1907 dealt with events before the end of the fifteenth century, as did nearly half of those in the massive Pageant of London, which, despite forming part of the 1911 Festival of Empire, had much to say about the pre-imperial past. ${ }^{26}$ On one level, the dominance of the medieval is not surprising: irrespective of one's exact definition of the period, there was around a millennium of history to draw on: by contrast, historical pageants in the United States drew, out of necessity, on the colonial era and more recent history. ${ }^{27}$ Nevertheless, in England the decision to end most Edwardian historical pageants in the sixteenth or seventeenth century demonstrates the power of the Middle Ages in the historical imagination. Even during the interwar years and into the 1950s, although there was a growing tendency to portray more recent periods of history, the medieval was still heavily represented:

\footnotetext{
${ }^{23}$ A.D. Smith, The Ethnic Origins of Nations (Oxford, 1988 [1986]), p. 188.

${ }^{24}$ The Sherborne Pageant: June 12th to 15th, 1905 (Sherborne, 1905).

${ }^{25}$ Book of Words of the Historical Episodes Presented at the Celebration of the Millenary of the City of Oxford, July 11, 1912 (Oxford, 1912).

${ }^{26}$ Liverpool's 700th Anniversary Celebrations: Words and Music, August 1907 (Liverpool, 1907); Sophie C. Lomas, Festival of Empire: Souvenir of the Pageant of London (London, 1911).

${ }^{27}$ D. Glassberg, American Historical Pageantry: The Uses of Tradition in the Early Twentieth Century (Chapel Hill, NC, 1990).
} 
for example, at Leicester in 1932, thirteen of the twenty-one scenes were set between the fall of Rome and the end of the sixteenth century, and at St Albans in 1953 six of the ten episodes were medieval, with the four others set in Roman times, 1577, 1692 and the nineteenth century. ${ }^{28}$ As we will show in this article, the ways in which the medieval past were presented changed, in some respects significantly, between the 1900s and the 1950s, but the appeal and resonance of the period itself remained to a very large extent undiminished.

Given their persistent emphasis on medieval subject-matter, it is surprising that pageants do not feature significantly in the large literature on medievalism and its varied embodiments in the modern world. ${ }^{29}$ They are notably absent from David Matthews's recent history of medievalism in Britain and beyond, and from other works. ${ }^{30}$ However, Matthews does offer a useful interpretive framework for some of the issues that emerge from an examination of medievalism in pageantry. Distilling earlier taxonomies devised by Umberto Eco and others, Matthews identifies two main 'versions' of the Middle Ages that characterise popular medievalism: the 'grotesque' and the 'romantic'. Grotesque medievalism is associated with horrors such as torture, plague and poverty, whereas romantic medievalism, which emerged as a strong cultural force in the late eighteenth century, emphasises 'the Middle Ages... of chivalric deeds, but also of simple communitarian living and humanely organised labour, a pastoral time when the cash nexus was unknown, a time of intense romantic love'. ${ }^{31}$ This version of the Middle Ages underpinned the Gothic revival and was

\footnotetext{
${ }^{28}$ Pageant of Leicester: Text of the Episodes (Leicester, 1932); Freeman, “"Splendid Display", p. 434.

${ }^{29}$ A typical example is M. Alexander, Medievalism: The Middle Ages in Modern England (New Haven, CT, 2007). Peter Meredith has examined the eighteenth- and nineteenth-century processional pageants in honour of Bishop Blase: 'Reading a Procession: Bishop Blase at Bradford', in D. Matthews, ed., In Strange Countries: Middle English Literature and Its Afterlife: Essays in Memory of J.J. Anderson (Manchester, 2011), pp. 108-31.

${ }^{30}$ D. Matthews, Medievalism: A Critical History (Woodbridge, 2015); V. Ortenberg, In Search of the Holy Grail: The Quest for the Middle Ages (London, 2006).

${ }^{31}$ Matthews, Medievalism, p. 25.
} 
propounded by John Ruskin, William Morris and other Victorian medievalists. Two associated concepts are the 'constitutional Middle Ages' and the 'civic Middle Ages', which respectively emphasise political and urban/cultural history, and which both played an important role in the popular representation of the past through historical pageants. According to Matthews, both romantic and civic medievalism 'received a severe check in Britain in the early years of the twentieth century', particularly after the very modern horrors of the First World War; however, others have argued that some aspects of civic medievalism remained influential during the interwar years. ${ }^{32}$

The concepts of the constitutional and civic Middle Ages are particularly useful for our purposes here. We will argue that historical pageants demonstrate an ongoing engagement with romantic, constitutional and civic medievalism into the mid-twentieth century, especially at local level, where the classical past had not 'displaced' the medieval to the extent that Matthews suggests elsewhere. ${ }^{33}$ Indeed, the medieval past remained a central component of the national and local community identities that were promoted and reflected in historical pageants up and down the country, at least until the Second World War and, to some extent, thereafter. However, the central elements of medievalism evolved, and the balance between the different types identified by Matthews shifted in a number of ways. In the early pageants, before the First World War, we show that both local and national identities were supported by representations of the medieval past; pageants in this period were particularly focused on the medieval — and especially the Anglo-Saxon — roots of the English nation and of the Christianity that was held to be a central aspect of it. Pageants celebrated the versions of continuous English nationhood that Smith identifies as part of the project of 'ethnic map-making' that occurred between the eighteenth and nineteenth

\footnotetext{
${ }^{32}$ Ibid., p. 30. See M.T. Saler, The Avant-Garde in Interwar England: Medieval Modernism and the London Underground (Oxford, 2001).

${ }^{33}$ Matthews, Medievalism, p. 5.
} 
centuries. ${ }^{34}$ In the interwar period, the balance shifted towards a focus on the later Middle Ages as the period where both English constitutionalism and the modern civic community were seen to have originated. In different ways, the medieval past was — as Phyllis Rackin has commented in relation to Shakespeare's medieval plays - 'idealized as a time of stable values and national glory', and this theme was apparent at least until $1939 .{ }^{35}$ Yet at the same time the medieval past was important as the origin of the civic communities that were celebrated in the pageants themselves. After the Second World War, however, we show that the constitutional 'uses' of the medieval past were less immediately apparent to those who staged historical pageants, and a looser form of engagement with the Middle Ages increasingly came to dominate, one influenced by developments in wider culture, and in the new broadcast media in particular. Pageants could still serve a civic purpose, but medievalism — and indeed, perhaps history in general — did not perform the same role in the shaping of national and local identities.

Our main sources are the published scripts and souvenir programmes from historical pageants, supported by press coverage and some archival material. Most major pageants produced 'books of words', which sold in large numbers and were often read by members of audiences as pageants were taking place: in many cases, and especially in the earlier part of the twentieth century, it was difficult or impossible to hear the dialogue due to a lack of amplified sound. Books of words reached wide audiences: for example, in Oxford in 1907, the book sold 17,000 copies even before the pageant started, and the souvenir publication at Plymouth in 1953 sold 20,000, which was only slightly less than the total audience for the pageant. ${ }^{36}$ We use these sources to consider in particular the depiction of particular themes

\footnotetext{
${ }^{34}$ Smith, Ethnic Origins, pp. 205-6.

${ }^{35}$ P. Rackin, 'English History Plays', in S. Wells and L.C. Orlin, eds., Shakespeare: An Oxford Guide (Oxford, 2003), p. 196.

${ }^{36}$ Readman, 'Place of the Past', pp. 173-5; 'The Pageant of Plymouth Hoe': http://www.historicalpageants.ac.uk/pageants/1165/ (accessed 29 Jan. 2017).
} 
and events, notably the Anglo-Saxons and Danes, medieval religion, the Norman Conquest and Magna Carta, and the ways in which the treatment of this subject-matter evolved during the twentieth century. As Yoshino has demonstrated for the Roman and Tudor and Stuart periods, ${ }^{37}$ examining the ways in which the national and local past was dramatically reenacted can offer many insights into the historical understandings that script-writers were trying to convey. It is important, however, to acknowledge the limitations of this approach: even where audiences could hear or read the words, or both, we should be wary of assuming that the 'messages' of pageants were 'read' in exactly the ways that their organisers wanted. ${ }^{38}$ However, the published ephemera produced by these large community events can provide useful insights into the versions of the medieval past that were available to twentieth-century audiences, and the ways in which the creators of pageants expressed the relationship between local and national identity through historical drama. The importance of the medieval past to the authors and producers of historical pageants is clear from these sources, and warrants deeper investigation.

This article focuses on England, but it is important to note the popularity of historical pageants in other parts of the British Isles, and indeed beyond. In both Scotland and Wales there were 'national' pageants before 1914, and many local ones too; these traditions continued to flourish during and after the interwar period. The town of Arbroath has staged no fewer than eighteen pageants since the Second World War, the most recent being in 2005; here the pageants focused on the Declaration of Independence of 1320, a central component of Scottish historical memory. ${ }^{39}$ Both Welsh and Scottish pageants also saw in the medieval period the origins of modern nations and the source of national identities, as well as the birth

\footnotetext{
${ }^{37}$ Yoshino, Pageant Fever, chapters 3-4.

${ }^{38}$ Ibid., pp. 99-101; Ryan, “"Pageantitis"”, pp. 66, 75-6.

${ }^{39}$ See L. Fleming, 'Still Going! Pageantry in Arbroath', 7 Apr. 2016: http://www.historicalpageants.ac.uk/blog/still-going-pageantry-arbroath/ (accessed 20 Apr. 2016).
} 
of the civic cultures that many pageants also celebrated, although unsurprisingly the focus was usually on different episodes and characters. ${ }^{40}$ Meanwhile, the pageant tradition took root in Ireland, where, as Joan FitzPatrick Dean has recently shown, it played a significant role in expressions of cultural nationalism. ${ }^{41}$ Parker and his pageants were also influential across the Atlantic, where, following the Philadelphia pageant of 1908, the American Pageant Association was formed in $1913 .^{42}$ The leading scholar of American pageants, David Glassberg, sees English historical pageants as mainly conservative and backward-looking spectacles, ${ }^{43}$ but it is important to note that the pageant form was adopted by a varied range of political and other organisations for their own purposes, especially during the interwar years. Mick Wallis and Helen McCarthy have shown, for example, that historical pageants were used by 'Popular Front' and internationalist organisations respectively to promote their political causes; ${ }^{44}$ the format was broad and popular for much of the twentieth century. Historical pageantry also spread to imperial settings_-Frank Lascelles took it to Quebec, Cape Town and Kolkota, among other places_-but these developments lie outside the scope of this article. ${ }^{45}$

\section{[LINE SPACE HERE]}

\footnotetext{
${ }^{40}$ See the detailed accounts of a large number of Scottish and Welsh pageants on the 'Redress of the Past' database: A. Bartie, P. Caton, L. Fleming, M. Freeman, T. Hulme, A. Hutton and P. Readman, The Redress of the Past, http://www.historicalpageants.ac.uk/pageants/

${ }^{41}$ J.F. Dean, All Dressed Up: Modern Irish Historical Pageantry (Syracuse, NY, 2014).

${ }^{42}$ Glassberg, American Historical Pageantry, pp. 46-52, 107-23.

${ }^{43}$ Ibid., 149-50.

${ }^{44}$ M. Wallis, 'Pageantry and the Popular Front: Ideological Production in the "Thirties"', New Theatre Quarterly, x (1994), pp. 132-56; id., 'The Popular Front Pageant: Its Emergence and Decline', New Theatre Quarterly, xi (1996), pp. 17-32; H. McCarthy, 'The League of Nations, Public Ritual and National Identity in Britain c.1919-56', History Workshop Journal, 1xx (2010), 108-32.

${ }^{45}$ J. Piggott, 'Lascelles, Frank William Thomas Charles Christian Culpepper (1875-1934)', Oxford Dictionary of National Biography: http://www.oxforddnb.com/view/article/56784 (accessed 8 Mar. 2017).
} 
English historical pageants before 1914 drew heavily on the medieval past. To an extent, this was an inheritance of eighteenth- and nineteenth-century interest in the Anglo-Saxon period, which culminated in the cult of King Alfred and the celebrations of his millennium, centred on Winchester, in 1901 (though it is now known that Alfred died in 899 and not 901). ${ }^{46}$ The Victorian cult of the Anglo-Saxons saw them as the founders of English law and government, and the source of the modern-day liberties of the 'freeborn Briton' ${ }^{47}$ Importantly, they were also identified as the main source of English Christianity, with heroes such as Alfred given starring roles in the story of its establishment against the odds. Therefore, although prehistoric and Roman scenes certainly featured, the national story was presented in pageants as originating in the medieval period, and — in pageants before 1914 -particularly in the years before the Norman Conquest. Inspiration for the present was drawn from the AngloSaxon era, but also from subsequent political and religious developments; medieval history provided various lessons for pageanteers and their audiences. Edwardian pageantry built on the romantic medievalism that had characterised the previous century and a half, but it also demonstrated some of the 'uses' of the constitutional and civic Middle Ages.

One aspect of pre-Conquest history that was given considerable attention was resistance to Danish aggression. The pageants of Sherborne (1905), Warwick (1906), Romsey (1907), Bury St Edmunds (1907), Oxford (1912), Stafford (1913) and Hertford (1914), among others, featured stirring scenes of Anglo-Saxon sacrifice and defiance in the face of the Danish threat. ${ }^{48}$ Unsurprisingly, the struggle with the Danes also appeared in the 1908

\footnotetext{
${ }^{46}$ Ortenberg, In Search of the Holy Grail, pp. 102-8; S. Keynes, 'The Cult of King Alfred the Great', Anglo Saxon England, xxviii (1999), pp. 225-356; J. Parker, England's Darling: The Victorian Cult of Alfred the Great (Manchester, 2007); Readman, 'Place of the Past', pp. 151-2 and n. 16.

${ }^{47}$ C.A. Simmons, Reversing the Conquest: History and Myth in Nineteenth-Century British Literature (New Brunswick, NJ, 1990); A. Briggs, 'Saxons, Normans and Victorians', in The Collected Essays of Asa Briggs (3 vols., Brighton, 1985-91), ii. 215-35.

${ }^{48}$ Sherborne Pageant; The Warwick Pageant, July 2, 3, 4, 5, 6, 7, 1906: In Celebration of the Thousandth Anniversary of the Conquest of Mercia by Queen Ethelfleda, Invented and
} 
Winchester pageant, where the opening episode showed Alfred's triumph over them, a victory attributed in part to the attention he paid to naval defence; this was a topical emphasis in the context of the escalating arms race with Wilhelmine Germany. 'Twas by our fleet that we broke the Danish power', Alfred declared at the close of this episode; 'I'll leave thy England this for legacy./There's your defence- the sea-look to your ships' ${ }^{49}$ As this might suggest, pageants' glorification of the struggle with the Danes could be linked to the aggressively militaristic spirit that some historians have identified as a pervasive aspect of Edwardian British politics and culture. ${ }^{50}$ However, the accent throughout was on dogged defence, rather than expansionism or jingoism. In the second episode at Sherborne, for example, the armour-clad Bishop Ealhstan was shown leading a motley group of townspeople to an unlikely victory over the well-armed Danes in 845: 'For God and Home!', he cried, driving the enemy back in hand-to-hand combat. ${ }^{51}$ Similar scenes featured elsewhere, often supplemented by portrayals of the conversion of captured Danes to Christianity. ${ }^{52}$ This was one aspect of the story of religious unity that was celebrated in pageant narratives, which will be explored in more detail below.

One corollary of a focus on the Anglo-Saxon past was a lamenting of the Conquest, and of the 'Norman yoke' of authoritarian government against which the common people had struggled through the centuries. ${ }^{53}$ This perspective- - which could at times segue into a racial

Arranged by Louis N. Parker (Warwick, 1906); Romsey Millenary Celebration: Words and Music (Romsey, 1907); St Edmundsbury Pageant 8th to 13th July 1907 Book of Words (Bury St Edmunds, 1907); Book of Words ... Oxford; Stafford Millenary Celebration Pageant: Souvenir Guide (Stafford, 1913); P. Sheail, Hertford's Grand Pageant 1914 (Hertford, 2014). ${ }^{49}$ Winchester National Pageant: The Book of the Words and Music (Winchester, 1908), episode I. References to books of words in this article will be to the 'episodes', although in the originals these are sometimes styled 'scenes' or 'acts'.

${ }^{50}$ For a classic treatment, see A. Summers, 'Militarism in Britain before the Great War', History Workshop Journal, ii (1976), pp. 104-23.

${ }^{51}$ Sherborne Pageant, episode II.

${ }^{52}$ Warwick Pageant, episode III.

${ }^{53}$ C. Hill, 'The Norman Yoke', in J. Saville, ed., Democracy and the Labour Movement (London, 1954), pp. 11-66. 
Anglo-Saxonism ${ }^{54}$ — culminated in the Winchester celebrations of 1901, and some Edwardian pageantry was, to an extent, faithful to this interpretation. The Normans could be depicted as violent and brutal, just as they had been in many nineteenth-century accounts, not least in school textbooks. ${ }^{55}$ At Sherborne, William I appeared as a stereotypical tyrant, shown entering the abbey in 1075 wearing full armour and followed by armed knights. William abruptly drew his giant sword and, smashing it down on a table in front of the terrified monks, told them: 'Sherborne is no longer a See. Your Church is no longer a cathedral. Your town no longer the chief city of Wessex. ${ }^{56}$ William was also negatively portrayed at Winchester in 1908, where one episode depicted him as a stern, unbending ruler who callously sent the Saxon earl Waltheof to his death. Given Winchester's history, this portrayal is unsurprising: the pageant, billed as a 'national pageant', presented Alfred the 'Hero-king' as 'the founder of the British system of good government', the Angles and Saxons as 'the main roots of the English nation', and Winchester itself as 'the cradle and home of our Anglo-Saxon race'. 57

Pageants in northern England presented particularly negative accounts of early Norman rule. At Thirsk in 1907, the second scene featured Baron de Ferrars carrying out the Domesday survey in 1087, as local thanes pledged unwilling loyalty to the king and told Ferrars what land they owned, and a chorus of 'Saxon churls' lamented their feudal workloads. ${ }^{58}$ Similar emotions were on display at Pickering in 1910. In this pageant, the

\footnotetext{
${ }^{54}$ See for example R. Horsman, 'The Origins of Racial Anglo-Saxonism in Britain before 1850', Journal of the History of Ideas, xxxvii (1976), 387-410.

${ }^{55}$ V.E. Chancellor, History for their Masters: Opinion in the English History Textbook 18001914 (Bath, 1970), 118-19.

${ }^{56}$ Sherborne Pageant, episode V.

${ }^{57}$ Frank Oaten, Characters in the National Pageant and their Impersonators (St Albans, 1908), p. 11; Hampshire Independent, 20 June 1908, p. 9; Col. J.F. Lewis, Short Historical Notes on the Winchester Pageant (Winchester, 1908), p. 1.

${ }^{58}$ The Thirsk Historical Play (Thirsk, 1907), episode II.
} 
Domesday scene depicted the local people in 1086, still feeling the effects of the "harrowing of the north' some sixteen years earlier. They sang the 'English Lament':

Nothing is left for thy Normans to crave.

Black is the land from the Tyne to the Humber;

All our fair country is one mighty grave.

Wrathful we list to the toll of the curfew;

Sullen we head to the lot of the slave.

Less worth are we than the deer of the forest;

Lost is all hope save the hope of the grave. ${ }^{59}$

The suffering Yorkshiremen were now asked to provide information for the Domesday survey, and the depredations continued, as Ralph de Bolbeck was appointed steward of the manor and the king ordered a new castle and church to be built at Pickering. Bolbeck ended the scene by ordering the people: 'Back to your kennels, dogs, and serve the King, or worse shall follow!- Soldiers, drive them hence! ${ }^{60}$

Notwithstanding the persistence of such Anglo-Saxon biases, however, pageants revealed some shifts in opinion as to the competing virtues of the pre- and post-Conquest pasts. Even at Winchester, the heart of Anglo-Saxon England, the pageant literature insisted that the Normans were not all bad: William had reorganised the church and in the longer term 'greatly promoted the cause of liberty by compelling the nobles to make common cause with the people'. ${ }^{61}$ As for the sainted Waltheof, his death symbolised 'the broadening of the

${ }^{59}$ The Book of the Pickering Pageant (or Historical Play), Arranged by Gilbert Hudson, August 10, 11, 12, 13, 1910 (Pickering, 1910), p. 20.

${ }^{60}$ Ibid., p. 22.

${ }^{61}$ Oaten, Characters in the National Pageant, p. 20. 
national life by the infusion of Norman vigour, and Norman largeness of statesmanship' ${ }^{62}$ This point was made more effectively, and more strongly, elsewhere. At Dover in 1908, William I was shown magnanimously acknowledging the valour of the men of Kent by offering them liberty in return for loyalty; they enthusiastically assented, chanting 'Hail, William!', to which he responded by granting them the title of 'Invicta' and promising to establish a priory in repentance for having earlier condemned to death the constable of Dover castle. ${ }^{63}$ Some pageants went further still, presenting the Conquest as a breath of new life into a society that was less virtuous than had previously been imagined. Saxon slave markets featured in two Gloucestershire pageants, while at Pevensey in 1908 — close to the site of the Battle of Hastings - the Saxons were presented as having gone from being murderously rapacious during their fifth-century invasions, slaughtering women for fun, to indolent lovers of drink and song by $1066 .{ }^{64}$ Indeed, the idea that the Anglo-Saxon polity had fallen into decay by the eleventh century was a theme in a number of pageants. In this vein, the Romsey pageant of 1907 declared that 'the stern courage and noble ideals of the race of Alfred' had 'given place to sloth and luxury and careless lives' by the mid-tenth century. In this pageant the marriage of the 'Norman prince' King Henry I to the 'English maiden' Princess Eadgyth (Edith) was presented as the event through which 'the two warring nations' were 'blended in one English people'. ${ }^{65}$

Edwardian pageants, then, did not present the Conquest as the destruction of a great civilisation: although some elements of the 'Norman yoke' remained, there was a growing tendency to emphasise continuity before and after 1066. The Conquest was not a great setback in the telos of national progress, but had helped advance it. Even at Thirsk, this was

\footnotetext{
62 Winchester National Pageant, p. 25.

${ }^{63}$ Louis N. Parker, The Dover Pageant: Book of the Words (Dover, 1908), episode II.

${ }^{64}$ The Times, 6 July 1908, p. 12; Daily Graphic, 4 Sept. 1911, p. 9; Pevensey Historical Pageant (Pevensey, 1908), episodes 2, 4.

${ }^{65}$ Romsey Millenary Celebration, pp. 37, 38.
} 
tentatively but hopefully acknowledged by the Saxon chorus, who looked forward to better things from their new rulers in due course:

Let us away! These Norman Earls

Care nought for us, poor Saxon churls.

And yet, perchance, their base-born King

Will bring to birth some nobler thing.

An English realm, where all are free,

Where poor and rich shall equal be;

Where child and mother without fee

May pass unharmed from sea to sea. ${ }^{66}$

The notion of continuity from Anglo-Saxon to Norman had, of course, been acknowledged by nineteenth-century historians such as William Stubbs and E.A. Freeman, ${ }^{67}$ but theirespecially Freeman's - partiality to the Anglo-Saxons was not necessarily reflected in pageant narratives.

Some pageanteers could even poke fun at the Anglo-Saxon past: the novelist and literary critic Arthur Quiller-Couch, who wrote two scenes for the Winchester pageant, was a case in point. His 1911 novel Brother Copas features a pageant in the fictional cathedral city of 'Merchester', a thinly disguised Winchester. Here the eponymous pageanteer, while admitting that Alfred had managed 'to galvanise 'em for a while', slated the Anglo-Saxons as

${ }^{66}$ Thirsk Historical Play, episode II.

${ }^{67}$ William Stubbs, The Constitutional History of England in Its Origin and Development (3 vols., Oxford, 1874-8), i.; E.A. Freeman, The History of the Norman Conquest of England, Its Causes and Its Results (Oxford, 1867). 
a herd of tall, flabby, pale-eyed men, who could neither fight, build, sing, nor enforce laws. And so our England—wise as Austria in mating — turned to other nuptials and married William the Norman. Behold them a new breed; the country covered with sturdy, bullet-headed, energetic fellows who are no sooner born than they fly to workhammers going, scaffolds climbing, cities, cathedrals spring up by magic... All this talk of Anglo-Saxons, Celts, and the rest, is rubbish. We are English by chemical action of a score of interfused bloods. ${ }^{68}$

This was a fictional representation of an atypical pageanteer, but a version of this perspective was found in many pageants: the national essence was no longer Anglo-Saxon pur sang, but rather a good deal of England's identity and strength was derived from ethnic and cultural intermixing, the various peoples ultimately finding unity in a common Christianity. Such a view represented a considerable change from the more exclusive Anglo-Saxonism previously in the ascendancy, and contrasted with the emphasis on ethnic and cultural homogeneity that could be found in other European nationalist movements of eighteenth and nineteenth centuries. ${ }^{69}$ Celebration of the mixed medieval origins of the modern English people could also be found in other contexts. One notable example was the rehabilitation of the Norsemen in the Lake District by W.G. Collingwood and other antiquaries and historians, for whom the arrival of the Vikings had resulted in a felicitous 'commixture of races': Celts, Norsemen, Welsh, Saxons and Angles all blended together to local and national benefit. ${ }^{70}$ This theme

${ }^{68}$ Arthur Quiller-Couch, Brother Copas (Bristol, 1911), p. 157.

${ }^{69}$ Ortenberg, In Search of the Holy Grail, 93-4. On the importance of ethnicity to modern constructions of national identity, see in particular Smith, Ethnic Origins. See also C. Calhoun, 'Nationalism and Ethnicity', Annual Review of Sociology, xix (1993), esp. pp. 22930 (for remarks on the 'internal homogeneity' often demanded by nationalism).

${ }^{70}$ M. Townend, The Vikings and Victorian Lakeland: The Norse Medievalism of W.G. Collingwood and his Contemporaries (Kendal, 2009), p. 196. 
was often emphasised in pageants, which aimed — as The Times declared at the height of 'pageant fever' - 'to show the various peoples who have conquered and inhabited England, welded together into one Church and one people'. ${ }^{71}$

After the Conquest, the action often moved to episodes where a united England fought against a common enemy. At Thirsk, the scene after Domesday Book was the Battle of the Standard in 1138, where Archbishop Thurstan of York made a stirring speech, the soldiers sang 'Men of England', and the Scottish army was defeated. ${ }^{72}$ At Chester, where the Conquest did not feature in the pageant, there was a scene set in 1189 in which Archbishop Baldwin of Canterbury preached a sermon encouraging the 'valiant English' to 'follow the Cross' and join the Third Crusade. ${ }^{73}$ In the south of England the common enemy was more likely to be France, though in fact medieval wars against the French did not feature prominently in pageants at this time, perhaps due to the international political environment: indeed, a 'pageant' (actually a procession and tableau) was held at St Albans in 1909, with guests from the town of Caen in Normandy, to mark the entente cordiale. ${ }^{74}$ So far as medieval domestic strife and civil war was concerned, this could not be avoided entirely- the Wars of the Roses appeared in many pageants — but overall the message was one of stability and social peace. Notably, the Peasants' Revolt and other moments of medieval social unrest rarely featured, and where they did, lessons were drawn from them about the strength of English constitutionalism and the value of wise royal leadership. ${ }^{75}$ The constitutional lessons of the Middle Ages became still more important in the pageants of interwar England, but they were clear even in the 1900 s.

71 The Times, 26 June 1908, p. 12.

72 Thirsk Historical Play, episode III.

${ }^{73}$ Chester Historical Pageant, July 18th to 23rd 1910, 2.45pm: Book of Words (Chester, 1910), episode IV.

${ }^{74}$ Charles H. Ashdown, St Albans - Caen 1909: 'In the Footsteps of the Conqueror' (St Albans, 1909); M. Freeman, St Albans: A History (Lancaster, 2008), p. 251.

${ }^{75}$ Freeman, “"Splendid Display”, pp. 435-6, 450-1. 
Another significant aspect of the treatment of medieval history in Edwardian pageants was the prominence of Christianity and - in particular — an emphasis on the long continuities of Christian worship in England, a story that went hand-in-glove with the political narrative of nationhood. The origins of Christianity were traced to the Roman period—at Warwick, for example, the first episode of the pageant showed Caractactus returning home from captivity in Rome to proselytise the heathen Britons, and of course Alban's martyrdom was a key episode at St Albans ${ }^{76}$ — but for the most part pageants celebrated a religious history that focused on the medieval period and that was bound up with national identity. As John Wolffe has shown, despite the inroads made by secular thought, a broad-based and — to a degreeecumenical Christianity remained a central element of English and British national identities deep into the twentieth century. ${ }^{77}$ Medieval religion was depicted in pageants as an inspiration to Anglo-Saxon resistance against the heathen Danes: the Thirsk pageant of 1907, for example, opened in the seventh century with a missionary preventing a human sacrifice by persuading the would-be Norse perpetrators to exchange their worship of Thor for the love of Christ. ${ }^{78}$ Later, the arrival of the Normans often featured the establishment or re-formation of an abbey or priory. Pageants celebrated an English Christian church united between the time of the Synod of Whitby in 664 and the ructions of the sixteenth and seventeenth centuries, the excesses of which—where depicted at all—were usually downplayed. The line generally taken in relation to the dissolution of the monasteries, for example, was that the religious orders had done a lot of good during the Middle Ages: they established institutions of learning, spread Christian values, and promoted philanthropy, and while some monks and

\footnotetext{
${ }^{76}$ Warwick Pageant, episode I; Charles H. Ashdown, The St Albans Pageant, July 15th to July 20th, 1907 (St Albans, 1907), episode III.

77 J. Wolffe, God and Greater Britain: Religion and National Life in Britain and Ireland, 1843-1945 (London, 1994). See also M. Grimley, 'The Religion of Englishness: Puritanism, Providentialism and "National Character" 1918-1945', Journal of British Studies, xlvi (2007), pp. 884-906.

${ }^{78}$ Thirsk Historical Play, episode I.
} 
nuns may have been lazy and venal in later years, they did not deserve the brutal treatment meted out to them by Henry VIII. ${ }^{79}$ Pageants emphasised the essential Christianity of the nation, and their popularity illustrated the continued purchase of religious understandings of nationhood - not so much the exclusive Protestantism identified by Linda Colley as forming the mainspring of a resurgent Britishness in the late eighteenth and early nineteenth centuries, but a more generalised sense of Christian faithfulness and its continuity through time. ${ }^{80}$

This celebration of Christian continuity reached its apotheosis in the English Church Pageant, staged at Fulham Palace in 1909. This pageant began with the promulgation in Britain of the edict of Constantine in 313, and its nineteen scenes - most of which were medieval — traced the development of Christianity down to the late seventeenth century past key landmarks including the arrival of St Augustine, the sacring of William the Conqueror and the murder of Thomas Becket. The sacring scene, set on Christmas Day 1066, was particularly significant, being chosen to show how the rite of anointing the English sovereign had remained substantially unchanged between its first performance in the eighth century and the coronation of Edward VII in 1901. ${ }^{81}$ The Church Pageant's insistence on the importance of Christianity to the long course of English national history can be read as a defensive reaction to what appeared to be secularising trends. Conscious that the theory of evolution had 'permanently altered the ways of human thought' and that 'Church History is hardly a factor in our present-day civilization at all', the Church Pageant organisers certainly hoped to reaffirm the role of Christianity in the twentieth century. ${ }^{82}$ And for all that their efforts stemmed from pessimism, they met with considerable success: despite some newspaper

\footnotetext{
79 'The Sherborne Pageant', Church Times, 16 June 1905, p. 778; Sherborne Pageant, episode IX; Romsey Millenary Celebration, episode VII; Lancaster Historical Pageant 1913: Book of Words by Halliwell Sutcliffe (Lancaster, 1913), episode V.

${ }^{80}$ L. Colley, Britons: Forging the Nation 1707-1837 (New Haven, CT, 1992).

${ }^{81}$ The Book of the English Church Pageant (London, 1909).

${ }^{82}$ Ibid., pp. 1-2.
} 
criticism, a smattering of religious controversy over the pageant's allegedly Catholic sympathies, and some atrocious weather, the pageant was watched by a total audience of 178,000 , with two additional performances being staged to accommodate demand. ${ }^{83}$ Moreover, although other pageants were by no means as saturated with religious history as this one, the importance of Christianity to national life was a preoccupation almost everywhere - a measure of the continuing purchase of a broad but indeterminate Christianity in the context of contemporaneous understandings of English identity.

Local religious history also played a part in pageants, which featured the establishment of churches and abbeys, and sometimes the martyrdom of local saints, as important moments in the stories of the communities whose history they celebrated. These local stories linked the national narrative with the specific experience of the community, and, in the case of especially important saints and religious houses, emphasised the role that particular places had played in the national story. The Pageant of Gloucestershire in 1908 showed the election of St Anselm as archbishop of Canterbury, which took place at Gloucester in 1093, supposedly against his will. ${ }^{84}$ At St Albans in 1907 the pageant showed King Offa founding the abbey — the traditional date for this was 793 — and predicting its future greatness. ${ }^{85}$ Sometimes these portrayals could shade into mystical religiosity. This was the case at Bury St Edmunds, whose pageant made great play with the story of St Edmund's martyrdom and the miracles associated with him and his shrine, and at Romsey, where the spirit of the dead Abbess Merwenna appeared in one scene to arrest the charge of the Danish

\footnotetext{
83 'The Church Pageant', The Times, 28 June 1909, p. 9.

${ }^{84}$ Gloucestershire Historical Pageant: Book of Words (Cheltenham, 1908), episode III; R. W. Southern, 'Anselm [St Anselm] (c.1033-1109)', Oxford Dictionary of National Biography: http://www.oxforddnb.com/view/article/572 (accessed 5 Feb. 2017). ${ }^{85}$ Ashdown, St Albans Pageant, episode IV.
} 
hordes, thus allowing the town's nuns to escape. ${ }^{86}$ As Louis Napoleon Parker had recommended, most pageants were preceded by a special church service on the Sunday before the first performance, and this was often packed to the rafters: 3,000 attended at Winchester, for example. ${ }^{87}$ Significantly, these services were also held in Nonconformist chapels and Catholic churches; they were not confined to the Anglican communion, although in some cases, such as Liverpool, pageants sparked denominational disputes relating to their content and organisation. ${ }^{88}$ The involvement of a range of churches, as well as other groups, in the local organisation of pageants emphasised Parker's aim — not always achieved in practice—of making each pageant a 'Festival of Brotherhood' ${ }^{89}$

The medieval period also featured heavily in pageants' presentation of the secular history of the communities in which they were enacted. Many of the towns that staged pageants in the Edwardian period had a notable medieval history and drew heavily on moments at which they had played a part, sometimes an incidental one, in larger national developments. ${ }^{90}$ The pageants at Pickering and Chester in 1910 and Stafford in 1913 showed Richard II as the prisoner of Henry Bolingbroke in those places; at Romsey in 1907 the body of William Rufus passed through following his death in the New Forest; examples could be multiplied. ${ }^{91}$ Elsewhere, the portrayal of royal visits enabled pageants to link the local with the national. At Colchester in 1909, scenes depicted Henry II and Queen Eleanor, Edward III

${ }^{86}$ St Edmundsbury Pageant, episode II; Romsey Millenary Celebration, episode III. See Tom Licence, 'The Cult of St Edmund', in Tom Licence, ed., Bury St Edmunds and the Norman Conquest (Woodbridge, 2014), pp. 104-30.

${ }^{87}$ Louis N. Parker, Several of My Lives (London, 1928), 279; Southern Daily Echo, 25 June 1908, p. 3.

${ }^{88}$ Hampshire Independent, 29 June 1907, p. 12; Cheltenham Looker-On, 11 July 1908, p. 5; 'The English Church Pageant', Aberdeen Journal, 11 June 1909, p. 5. On the churches and the Liverpool pageant, see M. Vickers, 'Civic Image and Civic Patriotism in Liverpool 18801914' (Univ. of Oxford D.Phil. thesis, 2000), pp. 69-73.

${ }^{89}$ Parker, Several of My Lives, p. 279.

${ }^{90}$ Readman, 'Place of the Past', pp. 176-7.

${ }^{91}$ Book of the Pickering Pageant, episode XI; Chester Historical Pageant, episode VI; Stafford Millenary Celebration, episode IV; Romsey Millenary Celebration, episode IV 
and Queen Philippa, Henry VI and Margaret of Anjou, and then Catherine of Aragon, visiting the town. While there, Philippa entreated the people to establish a trade in wool, and Margaret convinced Henry to spare the local fisheries - these visits highlighted aspects of local economic history as well as offering scope for the flamboyant representation of lavishly attired royal characters. ${ }^{92}$ Local political history was also important: some pageants celebrated the anniversary of a medieval civic charter, the septuacentenary in the case of the Liverpool pageant of 1907 , or some other foundation moment, such as the millenary of Ethelfelda's establishment of the burh of Stafford in 913. At Huntingdon, pageant fever arrived a little too late for a septuacentennial, but the first episode of the pageant of 1912 depicted King John's charter of 1206; a charter of the same year was also depicted at Stafford.${ }^{93}$ Sometimes the treatment of medieval urban history featured protests against unjust royal exertions - in Stafford's case market taxes—but this aspect was not usually given heavy emphasis. When it was, the scene invariably ended in a happy resolution, often accompanied with musical rejoicing. This focus on civic history — which would become, we argue, even more important after the First World War-was the counterpart of the national story that pageants also celebrated. In both cases, the medieval period was profoundly important, and clearly identified as the origin of modern national and local identities.

\section{[LINE SPACE HERE]}

With the onset of war in 1914, pageant fever went into remission. Schools, churches and youth organisations put on small-scale pageants, often for the purposes of raising funds for the war effort - and Parker himself staged some indoor pageants during the war-but the

\footnotetext{
92 Souvenir and Book of Words of the Colchester Pageant (Norwich and London, 1909), episodes III-V.

${ }^{93}$ Hinchingbrooke Pageant (Huntingdon, 1912), episode I; Stafford Millenary Celebration, episode III. Hinchingbrooke is just outside the town of Huntingdon.
} 
larger pageants that had characterised the Edwardian era were not performed. ${ }^{94}$ However, with the coming of peace the movement got under way again almost immediately, with a flurry of major pageants in 1919 and 1920. Pageantry remained strong through the 1920s and 1930s. Indeed, as the depression of the 1930s began to bite, pageants gained unprecedented traction in industrial towns and cities, which had not featured so prominently in the 1900s and 1910s: examples included Stoke-on-Trent (1930), Bradford (1931), Leicester (1932), Nottingham (1935), Manchester (1926 and 1938), and Birmingham (1938). ${ }^{95}$ London also took part, with many boroughs and suburbs staging pageants: examples include Islington (1922), Harrow (1923), Walthamstow (1930 and 1934), Dartford (1932) and Streatham (1936). ${ }^{96}$ The size of casts and attendances remained impressive: 78,000 people saw the Carlisle pageant of 1928 , which featured 4,000 performers..$^{97}$ The ongoing enthusiasm for pageants reflected the continued interest in historical subject-matter, and particularly that of medieval England. For script-writers and pageant-masters, the origins of the modern nation and of local communities remained firmly rooted in the medieval period, although — as we will now show - there were some notable shifts of emphasis in the 1920s and 1930s.

It has been suggested that the Great War did much to reduce levels of engagement with the medieval past, and that the Middle Ages went into retreat in some respects, for example in architecture and design. ${ }^{98}$ The war, so it is argued, fractured the sense of continuity between medieval and modern times - a continuity which, as we have seen, was important to pageant narratives. For Clare A. Simmons, 'the carnage of trench warfare was so

\footnotetext{
${ }^{94}$ See M. Lau, 'Performing History: The War-Time Pageants of Louis Napoleon Parker', Modern Drama, liv (2011), pp. 265-86.

${ }^{95}$ Hulme, "Nation of town criers"".

${ }^{96}$ T. Hulme, 'Civic identity and "the Octopus": Historical Pageants on the Border of Interwar London', Metropolitan History seminar series, Institute of Historical Research, London, 25 Nov. 2015.

${ }^{97}$ Yorkshire Post, 16 Aug. 1928, p. 12; Carlisle Great Historical Pageant 6-11th August 1928 (Carlisle, 1928), numbers on cover.

${ }^{98}$ See for example Alexander, Medievalism, p. 245.
} 
far removed from the vision of the Middle Ages that the Modernist period tends to reflect the Middle Ages as something desirable but unattainable, losing the sense of continuity with the past that the Victorians had fostered'. In this interpretation, cultural engagement with the medieval became fuzzier, moving away from history and towards temporally unspecific myth, legend, and romance. ${ }^{99}$ It is certainly the case that the popular culture of the interwar years engaged with the medieval past in loose and ahistorical ways. Film is usefully illustrative of this. In the early 1920s British filmmakers turned with some enthusiasm to medieval plot lines, many of which offered romance or melodrama rather than historical verisimilitude, with literature rather than history writing offering inspiration for screenplays. ${ }^{100}$ Yet, as Stefan Goebel has shown, medievalism was also prominent in the culture of commemoration after the war, and far from displaying an ahistorical or futuristic modernist aesthetic, war memorials drew heavily on pre-existing medievalist ideas and imagery. ${ }^{101}$ The prevalence of medieval idioms in post-war memorials demonstrates that, as Goebel writes, 'established interpretations of the First World War as a cultural turning-point in modern history cannot be sustained with regard to the culture of public remembrance'. In post-war British memory of the Great War, medievalism 'flourished' ${ }^{102}$ There was, moreover, also a new strand of 'medieval modernism' in the culture of interwar Britain, influenced by nineteenth-century medievalists such as Ruskin and Morris. Often provincial

${ }^{99}$ C.A. Simmons, 'Re-Creating the Middle Ages', in Andrew Galloway, ed., The Cambridge Companion to Medieval English Culture (Cambridge, 2011), p. 293.

${ }^{100}$ K.J. Harty, 'Robin Hood on Film: Moving Beyond a Swashbuckling Stereotype', in T. Hahn, ed., Robin Hood in Popular Culture: Violence, Transgression, and Justice (Cambridge, 2000), p. 91.

${ }^{101}$ S. Goebel, The Great War and Medieval Memory: War Remembrance and Medievalism in Britain and Germany 1914-1940 (Cambridge, 2007). On the First World War and historical pageants, see A. Bartie, L. Fleming, M. Freeman, T. Hulme, P. Readman and C. Tupman, "'And those who live, how shall I tell their fame?" Historical Pageants, Collective Remembrance and the First World War 1919-1939', Historical Research (published online, 8 June 2017).

102 Goebel, Great War, pp. 287, 286. 
rather than metropolitan in focus, medieval modernism drew on medieval motifs, in settings ranging from the Leeds Art Gallery to the London Underground, expressed through the simple directness of post-impressionist art. Thus medieval modernism had both an aesthetic and a social dimension, emphasising the importance of 'common' and 'living' art that played a role in shaping both the sensibilities and the political direction of modern societies and states. $^{103}$

\section{[FIGURE 2 NEAR HERE]}

In some respects medieval modernism could be said to have entered the historical pageantry movement, too. Pageant organisers used post-impressionistic styles in the advertising of their events; the covers of some books of words and souvenir programmes would not have looked out of place as examples of Frank Pick's London Underground posters (see Figure 2). ${ }^{104}$ Less common, but still notable, was the introduction of innovative modernist-inflected styles of abstract and interpretive ballet to some historical pageants. ${ }^{105}$ At Newark in 1936, the Wars of the Roses were portrayed through an abstract ballet featuring red and white soldiers - an approach to the conflict that was used later in other places such as Wolverhampton (1948) and Guildford (1957). ${ }^{106}$ Also some years later, at Bury St Edmunds in 1959, a 'Ballet of the Birth of Freedom' portrayed the impact of Magna Carta through a

\footnotetext{
${ }^{103}$ Saler, Avant-Garde, esp. chapter 1.

${ }^{104}$ See for example Nottingham and Notts Historical Pageant June 10th-15th 1935: Book of Words (Nottingham, 1935); Manchester Historical Pageant, June 27th to July 2nd, Displays and Searchlight Tattoo, July 4th to 9th 1938, Charter Centenary Celebrations (Manchester, 1938).

${ }^{105}$ On the genealogy of modernism in interwar dance, see R. Zimring 'Ballet, Folk Dance, and the Cultural History of Interwar Modernism: The Ballet Job', Modernist Cultures, ix, (2014), pp. 99-114.

${ }^{106}$ See The Pageant of Newark: Official Programme (Newark, 1936), episode II; Wolverhampton Centenary Pageant Souvenir Programme (Wolverhampton, 1948), episode V; The Pageant of Guildford: Official Programme (London, 1957), episode IV. The Newark ballet may have been influenced by the musical comedy of 1066 and All That, touring in 1936, which featured an interpretative War of the Roses ballet: Reginald Arkell and Alfred Reynolds, 1066 and all that: A Musical Comedy Based on that Memorable History by Sellar and Yeatman (London, c.1935).
} 
symbolic dance of characters representing common people, Injustice, Oppression, Freedom and the barons. ${ }^{107}$ More broadly, historical pageants certainly engaged with modern production techniques, heavily utilising the latest developments in stagecraft such as amplification, spotlighting, and moving stages. ${ }^{108}$

In terms of the actual pageant narratives, however, it was the relevance of medieval history to a modern industrialised and urbanised world, rather than modernist modes of expression, that remained central. Very few pageants ignored the Middle Ages completely, and most laid heavy emphasis on the importance of the period to the national and civic stories that were being told. The choice of venue often made this explicit: as before the war, many pageants were staged in medieval settings such as the grounds of old castles: Berkhamsted (1922) and Warwick (1930) are examples. ${ }^{109}$ In terms of content, medieval episodes generally accounted for between a third and a half of a pageant: at Salisbury in 1919, ten of sixteen episodes were set before 1600, and at Warwick in 1930 there were three medieval and two Elizabethan scenes out of a total of nine. ${ }^{110}$ Even where, as at industrial centres such as Birmingham or Manchester, there was no very significant medieval heritage, teleological narratives of growth from small medieval beginnings to nineteenth- and twentieth-century greatness were told by pageants, providing a usefully countervailing and comforting account of historical progress in the context of economic depression. One example was Bradford in 1931, which focused on the development of the locality as a great centre of textile manufacture, from the sheep-shearing of Norman times to the production of 'fine and smooth

${ }^{107}$ Bury St Edmunds Pageant of Magna Carta (Bury St Edmunds, 1959), episode VI.

${ }^{108}$ For an example see A. Bartie, L. Fleming, M. Freeman, T. Hulme, A. Hutton and P. Readman, 'The Greenwich Night Pageant', The Redress of the Past, http://www.historicalpageants.ac.uk/pageants/1076/ (accessed 26 July 2017).

${ }^{109}$ Berkhamsted Pageant Play: The Castle Grounds July 5th-8th 1922 (Berkhamsted, 1922);

R. Crompton Rhodes, The Spirit of Warwickshire: A Pageant (London, 1930).

${ }^{110}$ Children's Peace Pageant at Salisbury (Salisbury, 1919); Rhodes, Spirit of Warwickshire. 
cloths' in the days of the Plantagenets and beyond. ${ }^{111}$ Earlier, at Manchester in 1926, the pageant was based on the twelve murals of significant events in the city's history that decorated the town hall, painted by Ford Madox Brown between 1879 and 1893: these focused on the growth of Manchester's economic prosperity, and five of them were set in medieval times. One key episode showed the arrival of Flemish weavers in Manchester in 1363: the medieval past still mattered in Cottonopolis, even in the 1920s and 1930s. ${ }^{112}$ Here and elsewhere - including Carlisle in 1928 and Newcastle in 1931 - the pageant was held in association with a 'civic week': pageant organisers saw in the long continuities of their communities' pasts a means of mobilising and fostering citizenship, and so strengthening local identity. ${ }^{113}$

One important aspect of this was the commemoration of charters and the establishment of fairs and markets; another was the attempt to draw attention to the medieval forebears of the modern inhabitants of urban-industrial Britain. Pageant episodes thus focused positively on the lives of medieval peasants, locating their stories within broader narratives of significant events. The Dartford Pageant in 1932 offers one example. In a classic Civic Sunday pageant sermon, the Lord Bishop of Rochester (Dr Linton Smith) reminded the 5,000-strong crowd in the arena that the pageant helped 'to recall the splendour of past history, the great deeds that had made this country what it is to-day', including the 'common or ordinary men and women of days gone by who had done their share towards making this nation of ours what it is'. ${ }^{114}$ Scenes depicting the medieval period accordingly showed how the lives of the common people were affected by wider historical change. The second episode, set in 1066, played on notions of Kentish bravery, cunning and pride by showing

\footnotetext{
${ }^{111}$ Historical Pageant of Bradford: The Living Story of Bradford's Glory (Bradford, 1931), episodes III-IV.

${ }^{112}$ Historical Pageant of Manchester (Manchester, 1926).

${ }^{113}$ Hulme, "Nation of Town Criers", esp. 278-9 and 278 n. 60.

114 'Kent's Great Historical Pageant', West Kent Advertiser, 22 July 1932, p. 2.
} 
villagers tricking William the Conqueror into accepting terms beneficial to the locality. The third episode showed Edward the Black Prince visiting Hall Place in 1361, and concentrated on fun, frivolity and the celebration of ordinary village folk; it ended with Edward proclaiming that 'unity' prevailed 'despite the heavy burdens laid upon you', and predicting that 'your service and industry... will bring peace and prosperity to this great land of ours'words that may have been particularly apt in the context of the Great Depression. ${ }^{115}$

In keeping with the turn towards romance and legend, pageants also featured local folklore of medieval origin. This was not an entirely new development - the story of Guy of Warwick and his battle with the monstrous Dun Cow had been a highlight of the 1906 Warwick pageant, for example — but it became a particularly notable feature of the interwar period. Indeed, there was an entire pageant devoted to Guy at Guy's Cliffe near Warwick in $1927,{ }^{116}$ and in the 1930 Warwick pageant each scene was introduced with a dialogue between Guy and his lover Felice. Predictably, Robin Hood took a central role at Nottingham in 1935, and King Arthur also appeared more frequently than previously: he was especially popular in Welsh pageants, but was also seen at Carlisle in 1928, as well as Taunton in the same year. ${ }^{117}$ The inclusion of folk traditions was a matter of particular satisfaction to the American authority on historical pageantry, Robert Withington, who praised the inclusion at Salisbury of the St Christopher Giant model, a twelve-foot-high wooden figure that had featured in Salisbury civic celebrations since the fourteenth or fifteenth centuries. As he happily concluded, 'despite the changes wrought by the war, beneath an upheaval which

\footnotetext{
${ }^{115}$ Dartford Division of Kent Historical Pageant (Dartford, 1932).

${ }^{116}$ Hampshire Archives and Local Studies, Winchester (HALS), 9A06/C1, 'Pageant of the Life of Guy of Warwick', book of words.

${ }^{117}$ Nottingham and Notts Historical Pageant; Carlisle Historical Pageant, Souvenir Programme (Carlisle, 1928); M. Woods, 'Performing Power: Local Politics and the Taunton Pageant of 1928', Journal of Historical Geography, xxv (1999), pp. 57-74. For a Welsh example, see Fete and Pageant in Cardiff Castle in Aid of the Students' War Memorial Union (Cardiff, 1931), episode III, part III.
} 
seemed cataclysmic, English civilization still endures, and the spirit of the folk remains the same'. ${ }^{118}$ Yet, as in pre-war days, much of the medieval history told in pageants was still rooted in the historical record. Despite Parker's concern, expressed in 1929, that the pageant form was being 'vulgarised' by modern commercialism and overemphasis on gaudy show, ${ }^{119}$ a desire to celebrate and encourage an informed engagement with the past remained central to the movement — and in this project, the Middle Ages continued to loom large. Half the content of the Berkhamsted pageant of 1922, written by G.M. Trevelyan and Gilbert Hudson, had a medieval focus, for example, and its official symbol was the Black Prince, a regular occupant of Berkhamsted Castle in the mid-fourteenth century. ${ }^{120}$

There were, though, some important differences in the depiction of the medieval past compared with the pre-First World War pageants. In particular, although continuities between pre- and post-Conquest history were still sometimes emphasised, and although the AngloSaxon past commonly figured as part of local or national history, the importance of the period in pageantry was diminished after the war, in line with its declining purchase on English culture more generally. On the whole, fewer episodes were given over to purely Anglo-Saxon subjects, even heroes such as King Alfred, who was now far less popular than at the end of the nineteenth century: the last statue of the king had been erected at Pewsey in 1913, and he had little presence in popular culture after the Great War, being largely ignored in film, for instance. ${ }^{121}$ Significantly, perhaps, in the Dorset Pageant of 1929 Alfred's greatness is

\footnotetext{
${ }^{118}$ Robert Withington, 'Post-Bellum Giants', Studies in Philology, xviii (1921), p. 9.

${ }^{119}$ Parker, Several of My Lives, p. 297.

${ }^{120}$ Moorman, George Macaulay Trevelyan, p. 202; Peter Mandler, History and National Life (London, 2002), p. 71. We are grateful to Laura Carter for her research on the Berkhamsted pageant. On modern views of the Black Prince, see B. Gribling, The Image of the Black Prince in Georgian and Victorian England: Negotiating the Late Medieval Past (Woodbridge, 2017).

${ }^{121}$ B. Yorke, 'Alfredism: The Use and Abuse of King Alfred's Reputation in Later Centuries', in T. Reuter, ed., Alfred the Great: Papers from the Eleventh-Centenary Conference (Aldershot, 2003), p. 379; J.M. Parker, 'The Day of a Thousand Years: Winchester's 1901 Commemoration of Alfred the Great', in T. Shippey and M. Arnold, eds.,
} 
presented as residing more in his wise statesmanship, godliness and learning than in his martial prowess, although the familiar line about his founding of the British navy was repeated. Much, indeed, was made of the contribution of the women in Alfred's life, especially his mother, portrayed here as having taught him to read. ${ }^{122}$ Another key figure from before the war, Ethelfleda, was depicted less frequently, though she did appear in triumph, defeating Danish raiders, at Leicester in $1932 .{ }^{123}$ A number of local Anglo-Saxon heroes, particularly saints, found their way into pageants, such as St Birinus at Reading in 1920, St Cuthbert at Carlisle in 1928, and St Milburga at Claverley in $1931 .{ }^{124}$ However, in some pageants where the later medieval period figured prominently, there was no AngloSaxon history at all. ${ }^{125}$

Related to these developments was an increasingly positive view of the Norman Conquest. In this respect, Trevelyan's Berkhamsted pageant set the tone. Here, one episode showed William the Conqueror reaching Berkhamsted in the course of his rampaging march from Hastings. William was depicted as a hard man: the Saxon foot-soldiers yielded to his knights, and he showed no mercy to the defenders until they confessed themselves his subjects. Yet the pageant presented William's toughness not as cruelty, but expressive of his determination to effect national unity. Following the Saxon surrender, the episode went on to show the Conqueror receiving at Berkhamsted a deputation from London, who invited him to accept the English crown. William assented, and the episode closed peacefully, with the new

Film and Fiction: Reviewing the Middle Ages (Cambridge, 2002), pp. 128-9; K.J. Harty, The Vikings on Film: Essays on Depictions of the Nordic Middle Ages (Jefferson, NC, 2011), pp. $39-45$.

122 The Dorset Pageant Book of Words and Programme (Dorchester, 1929), episode II.

${ }^{123}$ Pageant of Leicester: Text of the Episodes (Leicester, 1932), episode III.

${ }^{124}$ Carlisle Historical Pageant, episode III; Book of Words of the Reading Historical Pageant (Reading, 1920), episode I; Historical Pageant of Claverley and its Neighbourhood (Shrewsbury, 1931), episode II.

${ }^{125}$ See for example the 1926 Hitcham House pageant, 'Pictures of Local History': programme in HALS, Barbara Drummond papers, 220M85W/13; Birmingham 1838-1938 Charter Centenary Celebrations, Official Programme (Birmingham, 1938). 
king ordering that Berkhamsted castle be built up as a great stronghold, and pledging to rule his new domain in such a way as to bring Saxon, Dane and Norman together in one nation. ${ }^{126}$ Other pageants, similarly, showed the Normans bringing order and national unity to a decayed and restive polity. At Nottingham in 1935, William was shown arriving to crush the northern revolt. Having done this, and quelled a local quarrel between Nottinghamshire magnates, he handed over the keeping of Nottingham castle to William Peverel, to ensure the maintenance of peace in the future. In response to this generosity, Peverel established and endowed the Cluniac Lenton Priory, and the episode ended in tranquillity with a hymn invoking God's blessing on the new foundation. ${ }^{127}$ Even William's successor, William Rufus, seen by many Victorians as a great scourge of English liberties, could appear in the guise of nation-builder. The Carlisle pageant of 1928 showed his deposition of the Scots-aligned Dolfin (son of the earl of Northumbria) as overlord of the town, an act that was presented as establishing Carlisle as a definitively English frontier stronghold, thus securing its future prosperity. ${ }^{128}$ This figuring of the Normans as stern but effective bringers of order, peace, security and national unity aligned with contemporaneous historical understandings of the Conquest period. ${ }^{129}$ Another king who brought order and stability was Henry II, whom the 1935 Nottingham pageant showed travelling around England destroying the adulterine castles that had sprung up during the disorderly reign of his predecessor Stephen, and by so doing establishing a strong central government. ${ }^{130}$ Such episodes may have had a special resonance for audiences given the interwar context of economic and political vicissitudes at home and abroad.

\footnotetext{
${ }^{126}$ Berkhamsted Pageant Play, episode IV.

${ }^{127}$ Nottingham and Notts Historical Pageant, episode III.

${ }^{128}$ Carlisle Historical Pageant, episode IV.

${ }^{129}$ M. Chibnall, The Debate on the Norman Conquest (Manchester, 1999), chapter 5.

${ }^{130}$ Nottingham and Notts Historical Pageant, episode IV.
} 
A conservative, patriotic constitutionalism was perhaps even more evident in the treatment of King John and Magna Carta. In the 1920s and 1930s pageants laid considerable emphasis on John's established reputation for rapaciousness and misgovernment, and on the redress effected by the action of the barons in 1215. Many pageants featured visits by John to the locality, an occasion offering him an opportunity not to instil order or foster loyalty as a 'good king' might have done, but to fleece the inhabitants through extortionate taxation or other means. At Sydling, Dorset, in 1925, for example, John was shown arriving supposedly to settle local disputes, but he ended up taking custody of two orphans in a sordid exchange for money, and imposing taxes on a local hospital - actions that led to prognostications on the part of the wronged that soon England's barons would rise up and win a charter to secure the nation's liberties. ${ }^{131}$ A similar prediction was made in the 1929 Dorset pageant, one episode of which featured the king's confiscation of the estates of a local magnate as punishment for accidentally shooting one of his favourite stags. ${ }^{132}$ Such use of King John in pageants was a means of invoking history to condemn a tyranny dangerous to national unity-dangerous because of its alienation of local leaders and local communities, and its reckless ungraciousness in the face of the simple loyalty of the common people. It was also a means of presenting a local heritage of patriotic virtue. In the face of such misgovernment the places so ill-treated by John on his travels were shown not rising in violent revolt against the crown, but aligning themselves in favour of the peaceable constitutional change embodied in the presentation of Magna Carta. (Pageant narratives generally avoided the civil war that followed 1215; where it did feature, as at Wisbech in 1929, the finger of blame was pointed at John, too weak to resist papal influence.) ${ }^{133}$ Thus the Leicester pageant of 1932 featured an episode in which local barons, including Robert Fitzparnel, earl of Leicester, were shown

\footnotetext{
${ }^{131}$ Ethel Ashburnham, Sydling Pageant 1925 (Dorchester, 1925), episode III.

132 Dorset Pageant, episode III.

${ }^{133}$ The Wisbech Pageant: The Heart of the Fens (n.p., 1929).
} 
discussing the depredations wrought by the king. Yet while some suggested immediate open resistance, they resolved instead to meet elsewhere to frame 'the Charter of our Country's rights' - a decision that prompted the figure of Fitzparnel to declare that 'here to-day in Leicester, England has found her soul' ${ }^{134}$

\section{[FIGURE 3 NEAR HERE]}

The handling of Magna Carta is a particularly good indication of the moderate and patriotic constitutionalism that pervaded interwar pageant narratives. Political reformers of the eighteenth and nineteenth centuries had often found in the famous document inspiration for advanced radical programmes, but by the 1920s and 1930s Magna Carta was of less service to the left than it was to the centre, and even the right, of the political spectrum. This was certainly the case at the Runnymede pageant, in 1934, staged in the actual meadows where the document had been presented. King John, granting the charter somewhat reluctantly, of course featured (see Figure 3), but the narrative was dominated by positive rather than negative depictions of the monarchy in British history. The pageant had a long list of aristocratic and royal patrons headed by the Prince of Wales and Duke and Duchess of York, and including prominent members of the Conservative party and the military establishment. ${ }^{135}$ The same year saw the Pageant of Parliament, a grand affair staged in the Royal Albert Hall and organised primarily by members of the Conservative party. ${ }^{136}$ The idea of parliament, the pageant suggested, originated with Magna Carta, which was the subject of the opening episode - there was, significantly, no attempt to identify Anglo-Saxon precursors to the medieval or modern parliament. At the end of the scene, King John was shown sealing the document, an act celebrated with the singing of a song of liberty, and the ensuing civil

\footnotetext{
${ }^{134}$ Pageant of Leicester, episode I.

${ }^{135}$ S. Vesey-Fitzgerald, Pageant of Runnymede, in Aid of Local Hospitals and Charities, June 19th to June 16th 1934 (London, 1934).

136 The Times, 10 Nov. 1933, 14. See E. Robinson, The Language of Progressive Politics in Modern Britain (Basingstoke, 2017), chapter 4, esp. pp. 114-15.
} 
war went unmentioned. ${ }^{137}$ With scenes like this, the pageant embodied a desire to promote mainstream constitutionalism in the face of political extremism in Britain and abroad. Treating the history of parliament as a linear march towards present liberty allowed the organisers to make claims about parliament's ability to adapt over centuries. As The Times pointed out, it was, at once, 'the most medieval thing in England, and the most modern'. ${ }^{138}$ This conservative constitutionalism was apparent throughout the medieval episodes of the pageant. The summoning of parliament in 1295 was presented as the doing of a wise king, Edward I, who had gathered his grateful people together to explain how best the monies raised for war could be spent. The episode went on to relate how parliament's approval of this taxation ensured that Edward was victorious against the Welsh, thus joining Wales to England in happy harmony and so furthering the cause of British greatness. ${ }^{139}$ Whereas in 1909 the English Church Pageant had taken historical pageantry from a local to a national stage, emphasising the key theme of Christian continuity and English identity, the Pageant of Parliament did the same for the 1930s, with the 'constitutional Middle Ages' as its defining inspiration.

The main focus of most interwar pageants, however, was on the local community and the continuities of local and national history that had shaped it. Linking the locality to the national story remained important, and hence many pageants continued to depict royal visits from the past, and moments where local and national histories intersected. At Chester in 1937, medieval scenes included the fortification of the city by Ethelfleda — whose appearances in pageants were somewhat rare by this time - the foundation of the abbey by Hugh Lupus, earl of Chester, and appearances by Edward I, Richard II and Henry of

137 'Magna Carta 1215', Pageant of Parliament (London, 1934).

138 'Parliament in Pageantry', The Times, 14 July 1934, p. 13.

139 'The First Great Parliament 1295', Pageant of Parliament. 
Bolingbroke. ${ }^{140}$ Much of this pageant emphasised the strategic importance of Chester in English and Welsh medieval history, and in some respects the pageant resembled its Edwardian predecessor of $1910 .{ }^{141}$ Even where pageants were staged in modern towns and marked modern historical events, such as the Birmingham charter centenary pageant of 1938, they drew heavily on local medieval history. At this pageant, produced by Gwen Lally, the second episode portrayed the granting of a market charter to Peter de Bermingham by Henry II, which — according to the official programme - marked the point at which the pageant 'concerns itself with matters concerning more intimately the history of Birmingham'. ${ }^{142}$ (The charter of 1838, in honour of which the pageant was staged, was not actually depicted in an episode.) Elsewhere, pageant promoters placed heavy emphasis on the medieval period as the origin of, and an inspiration for, the modern community. At Wisbech in 1929, where the whole pageant—written by Arthur Bryant — was centred on a fair in the time of King John, locality and nation were intertwined, as the event was preceded by the singing of the national anthem and the reading of the town's sixteenth-century charter. The local press urged Wisbechians to find 'a fresh zest' for the town's history, and to 'appreciate more of the privileges of the present day'. ${ }^{143}$ The emphasis on long historical continuities, on the links between the medieval past and the present, was designed to legitimise and strengthen both local and national identities in the context of twentieth-century modernity. Interwar historical pageants found inspiration from both the 'constitutional' and 'civic' Middle Ages, and the past fed directly into the construction of national and local identities. The series of historical

${ }^{140}$ Chester Historical Pageant, also Searchlight Tattoo, at Chester, July 5th to 10th, 1937: Official Souvenir Programme (Chester, 1937), episodes III-VI.

${ }^{141}$ There were both similarities and differences between the two pageants: see A. Bartie, L. Fleming, M. Freeman, T. Hulme, A. Hutton, P. Readman, 'Chester Historical Pageant', The Redress of the Past, http://www.historicalpageants.ac.uk/pageants/1029/ (accessed 1 Feb. 2017).

142 Birmingham 1838-1938 Charter Centenary Celebrations, p. 43.

${ }^{143}$ Wisbech Pageant; Isle of Ely and Wisbech Advertiser, 24 July 1929: Liddell Hart Military Archives, BRYANT J3. 
stories presented in pageants could still, in Smith's words, be seen as 'a moral teacher and a temporal and terrestrial drama of salvation', ${ }^{144}$ although after the Second World War this purpose would become more difficult to sustain.

\section{[LINE SPACE HERE]}

In 1939 as in 1914, the outbreak of war reduced the incidence of large-scale historical pageantry: for the most part during the war, only small events were staged, often organised by schools, youth groups or voluntary organisations. ${ }^{145}$ Yet once again 'pageant fever' showed its resilience, returning again in the later 1940s. Despite the constraints of post-war austerity, fairly large pageants were staged at, for example, Bristol (1946, with 760 performers and a total audience of over 10,000, but little medieval content), St Albans (1948, with 1,000 performers), and Nottingham (1949, with a cast of 700 and a total audience of 40,000; see Figure 4). Smaller towns and villages also returned to pageantry, with some quite obscure places recording notable successes: the pageant held in the village of Chilham, Kent, in 1946 was seen by around 10,000 people. ${ }^{146}$ These and other performances were followed by a flurry of pageants held to coincide with the Festival of Britain in 1951, and there was a further burst of activity around the time of the Coronation in 1953. That pageants remained popular during the 1950s was due in no small part to the energy of pageant-masters such as Anthony Parker (grandson of Louis Napoleon Parker, responsible for the Coronation pageant at Warwick Castle with 2,000 performers and more than 40,000 spectators), Cyril Swinson (who produced at least half a dozen pageants in the south-east of England as well as the

\footnotetext{
${ }^{144}$ Smith, Ethnic Origins, p. 179.

${ }^{145}$ See the examples in Bartie et al, Redress of the Past, http://www.historicalpageants.ac.uk/pageants/

146 The Times, 14 Nov. 1946, p. 7; St Albans Millenary Pageant 948-1948: Souvenir Programme, 21st-26th June 1948 (St Albans, 1948); City of Nottingham Quincentenary Pageant Souvenir Programme (Nottingham, 1949).
} 
Jersey pageant of 1955), and Christopher Ede. ${ }^{147}$ Ede was pageant-master at Guildford (1957) and Bury St Edmunds (1959), where in both cases medieval history featured prominently: at Bury, seven of the ten episodes were set in the Middle Ages, and at Guildford eight of eighteen were set in the period from 1257 (the date of the town's charter, given by Henry III) to 1538 (the dissolution of the friary). ${ }^{148}$ Medieval episodes were similarly prominent elsewhere. More than half the content was medieval at Poole in 1952, St Albans and Bridport in 1953, and many other places besides. ${ }^{149}$ Although both the incidence and scale of historical pageantry declined after the 1950 s, there were some notable events, including pageants at Berkhamsted in 1966, Carlisle in 1977, and in the small Dorset town of Axbridge in 1967, 1970 and every ten years thereafter. ${ }^{150}$

\section{[FIGURE 4 NEAR HERE]}

There were some continuities in the presentation of medieval history before and after 1945, but for the most part, the ways in which pageants depicted it were changing. AngloSaxon scenes appeared much less often, with few pageants containing more than one. ${ }^{151}$ Some echoes of the Norman yoke were still heard - in a scene at Rushden in 1951 set at the time of Domesday, it was noted that 'the people were little more than slaves', mired in 'toil, disease and ignorance ${ }^{152}$ — but this perspective was comparatively rare. Many pageants laid

${ }^{147}$ Leamington Spa Courier, 31 July 1953, p. 5; Warwickshire Coronation Pageant, Warwick Castle, July 17 to 25, 1953: Souvenir Programme (n.p., 1953); Freeman, “"Splendid Display"', pp. 439, 444.

${ }^{148}$ Bury St Edmunds Pageant of Magna Carta; Pageant of Guildford.

149 Pageant of Poole (Poole, 1952); St Albans Pageant 1953: Masque of the Queens, Verulamium, June 22-27, 1953, Souvenir Programme (St Albans, 1953); Bridport Royal Charter Pageant Souvenir Programme (Bridport, 1953).

${ }^{150}$ See A. Bartie, L. Fleming, M. Freeman, T. Hulme and P. Readman, 'Performing the Past: Identity, Civic Culture and Historical Pageants in Twentieth-Century English Small Towns', in Luda Klusakova, ed., Small Towns in Europe and Beyond: 20th-21st Century (Prague, 2017), pp. 24-51; The Carlisle Pageant '77: The Making of a Pageant (Carlisle, 1977); Somerset Heritage Centre, Taunton, PAM 89: 'Highlights from the History of an Ancient Royal Borough Presented by the People of Axbridge and District' (1967).

${ }^{151}$ For an exception see St Albans Millenary Pageant, episodes II-III.

${ }^{152}$ Pageant of Rushden 1951 (Rushden 1951), episode II. 
less stress on the moral lessons of history, in particular as these related to constitutional developments and examples of good and bad government. Even King John, who continued to figure prominently, often escaped serious criticism. In the 1953 Bridport pageant, for example, his order of 1213 that the people of the town work 'night and day' to supply the navy with ropes and cables was presented as beneficent encouragement of the local economy. In the performance, he was shown arriving in Bridport not to impose punitive taxation but to purchase rope, which he declared (to cheers from the audience) was 'the best in the world'. ${ }^{153}$ Perhaps influenced by trends in twentieth-century historiography, ${ }^{154}$ the 1967 Axbridge pageant suggested that while John 'was not a good man', no king had worked harder at the business of government, and he at least knew how to enjoy himself: one episode showed him hunting in the Royal Forest of Mendip. ${ }^{155}$ A few years later the tiny Pitminster pageant, staged in a parish church, went further still, presenting John as a fun-loving, even kindly figure, pardonably preferring hunting and other pleasures to pious religiosity. Chastised by the Bishop of Winchester for his lax approach to worship, John good-humouredly responded by asking the prelate to 'not spoil' his day of sport, and the scene concluded with the two men leaving for a feast, as costumed performers danced in the church aisles. ${ }^{156}$ Not all pageants were as kind to John, the 1959 Bury St Edmunds Magna Carta pageant being perhaps the best example. But even here John was portrayed more as pantomime villain than constitutional disaster. A cantankerous John was shown visiting the town on market day, around the year 1200 , the prosperity of the place prompting him to suggest a tax rise.

Swilling wine, he went on to dispense summary justice of various kinds, before appropriating the jewels his mother had laid at St Edmund's shrine and disingenuously promising a large

${ }^{153}$ Bridport Royal Charter Pageant, episode II.

154 J.C. Holt, Magna Carta (Cambridge, 1965).

155 'Highlights from the History of an Ancient Royal Borough'.

156 Pitminster and Corfe Festival: A Pageant of Our History (Pitminster, 1976), episode II. 
donation to the abbey, presenting as token of his intention an item already in the abbey's possession (borrowed for this purpose by one of his knights), and a purse of money — which after his departure was found to contain just 13 pence. $^{157}$

Although pageants still had a serious purpose, the treatment of the historical record was becoming looser, less serious and certainly less didactic than in earlier periods. Elements of this shift had been apparent before the Second World War, with the use of myth and legend alongside documented historical events, and this trend continued after 1945, with dragons and other mythical characters featuring quite prominently in various pageants. ${ }^{158}$ The balance was shifting from instruction to entertainment, despite the fact that pageants could, and did, claim exemption from the entertainments tax on the grounds that their content was 'wholly educational'. ${ }^{159}$ Elements of the 'grotesque Middle Ages' were making their way into the movement. In 1949 Nottingham's pageant-master, Lawrence du Garde Peach, made a pre-pageant speech at the city's Rotary Club, setting out his view that a historical pageant should be a cross between a revue, a musical comedy and a psychological play, and that as such it should also be

simply entertainment. It must compete with the cinema across the way, and the dance hall ... I would sacrifice any historical fact in order to get entertainment value in my script, although here I have had no need to. You [in Nottingham] had some of the most amusing and colourful murders in history. ${ }^{160}$

${ }^{157}$ Bury St Edmunds Pageant of Magna Carta, episode III.

158 'St George and the Dragon' was performed within a medieval episode at St Albans in 1953 (St Albans Pageant 1953, episode V); this was probably the inspiration for the story in a children's novel by Rosemary Manning, Dragon in Danger (London, 1959), where a dragon takes part in a pageant at 'St Aubyns'.

${ }^{159}$ Freeman, "'Splendid Display", pp. 425, 439.

160 'Pageant Worthy of City', Nottingham Evening Post, 28 Mar. 1949, p. 1. 
Peach was as good as his word, dealing with his medieval subject-matter-eight of seventeen episodes were medieval—in a mostly light-hearted manner. Thus the Saxon episode, set in 920, featured the building of the Trent bridge by Edward the Elder, but also a fanciful ballet and a humorous portrayal of the first attempt to collect tolls from the unwilling townspeople. There were certainly no serious messages about the 'Norman yoke': the 1066 episode ended with a great country fair. Unsurprisingly, Robin Hood featured again (see Figure 4), as he had in 1935, and this time the episode evoked swashbuckling cinematic portrayals of the legendary hero, no doubt influenced by Errol Flynn's famous performance in the 1938 Technicolor film The Adventures of Robin Hood. ${ }^{161}$ For Peach, the scenes of medieval revelry that he depicted in the pageant were an antidote to both modern and medieval realities - an interesting take on the escapism often associated with immersion in the medieval past:

We are going back to Merrie England - a fabulous England that probably never existed. In the real England the men marched off to fight at Crécy and Agincourt and came back to rotten houses and no drains, and no cars, and no B.B.C., and no telephones. ${ }^{162}$

Not all pageants in the immediate post-war period were as determinedly entertainmentfocused as Nottingham's, but there was a growing consensus that it was permissible, and perhaps desirable, to prioritise dramatic effect over fidelity to the historical record. This attitude to pageantry was not always popular, as some correspondence in response to Peach in the Nottingham press demonstrates; it was, however, increasingly common. ${ }^{163}$

${ }^{161}$ City of Nottingham Quincentenary Pageant, episodes II, IV, V; Hal B. Wallis and Henry Blanke (producers), The Adventures of Robin Hood (Warner Bros., 1938). On Robin Hood and his depiction in popular culture, see the work of Stephen Knight, most recently Reading Robin Hood: Content, Form and Reception in the Outlaw Myth (Manchester, 2015). 162 'Pageant Worthy of City'. 163 'Pageant of the Past', letter from E. Flewitt, Nottingham Evening Post, 8 July 1949, p. 4; Nottingham Evening Post, 31 Mar. 1949, p. 3. 
This does not mean that a serious message was lacking: if their depictions of past events were less reverential, pageants still had the purpose of stimulating pride in both the nation and the locality. Pageants could contribute to the celebration of 'timeless traditions' in the Festival of Britain, while some Coronation pageants focused specifically on the history of English queens, although many of the most important of these, of course, were not from the medieval period. ${ }^{164}$ In 1951, with the focus of the celebrations on Britain, and not England as such, the medieval origins of nationhood had less purchase in the Festival celebrations, and pageants downplayed this 'message' along with the Norman Yoke and Magna Carta. Thus, for example, at Brighton's festival-year pageant the 1066 episode focused on Harold raising his army; the battle itself and its aftermath were omitted. ${ }^{165}$ In 1953 few pageants depicted the Norman Conquest or the reign of William I, and Magna Carta was similarly rare, unsurprisingly perhaps in pageants staged to mark the coronation of a new monarch. ${ }^{166}$ Some pageants in the early post-war period avoided the eleventh, twelfth and thirteenth centuries entirely: at St Albans in 1948 there was no episode set between 948 and 1440, and the Festival pageant staged at Kingston, Richmond and Twickenham contained none between 924 and 1414; at Dartford in 1951 the only episode between the Romans and the fourteenth century was an undated May Day fair from the 'Middle Ages', while at Alnwick the first scene in the pageant was set in the sixteenth century. ${ }^{167}$

${ }^{164}$ B. Conekin, 'The Autobiography of a Nation': The 1951 Festival of Britain (Manchester, 2003), pp. 84, 100-3; St Albans Pageant 1953; The Queens of England Pageant: Souvenir Programme (Benfleet, 1953).

165 Brighton Pageant 1951: Cavalcade through the Ages (Brighton, 1951), episode II.

166 There was a Domesday Book scene in the Edwinstowe Coronation Pageant of 1953: Hilda Wilson and Angus Wilson, 'The Pageant of Edwinstowe', episode II: original script in Nottinghamshire Archives, PAC/94/12/9/15. King John appeared in episode III of the same pageant, but Magna Carta was not mentioned in this or any other pageant in 1951, 1952 or 1953 that appears in the database at http://www.historicalpageants.ac.uk/pageants/. ${ }^{167}$ St Albans Millenary Pageant; The Three Towns Pageant (London, 1951); Festival of Britain Dartford Historical Pageant 1951 (Dartford, 1951); 'Alnwick Pageant': http://historicalpageants.ac.uk/pageants/alnwick-pageant/ (accessed 1 Mar. 2017). 
Yet while the medieval past was less central to the national stories told in the pageants of the 1940s and 1950s, these performances still used the medieval past to stir local communities into action. This was made clear at Nottingham, where the Lord Mayor, in his introduction to the souvenir programme, explained that 'Our hope is that this Pageant may, through the medium of theatrical entertainment, enhance your knowledge of Nottingham's past, increase your pride of [sic] Nottingham's present, and strengthen your sense of responsibility for Nottingham's future. ${ }^{, 68}$ At Nottingham and in many other places, specially-written pageant hymns emphasised the power of history to stimulate pride and exertion in the present and future. As had been the case earlier in the century, some pageants celebrated local Anglo-Saxon saints: a small pageant in Newcastle in 1951, for example, marked the 1300th anniversary of the martyrdom of St Aidan by depicting various incidents from his life, and in the same year a Festival pageant at Ely told three stories from the life of the seventh-century abbess St Æthelthryth, with one fourteenth-century pilgrimage scene. ${ }^{169}$ More importantly, though, it was still possible to find the origins of urban communities in the medieval period, and it is striking that many post-war pageants celebrated the anniversaries of medieval charters and took dramatic inspiration from the long continuities of their existence. Examples include the pageant at Ipswich in 1951, which was part of the Festival but also marked the 750th anniversary of the charter given to the town by King John, and Swinson's King's Lynn Charter Pageant in 1954, also marking the 750th anniversary of one of John's charters. ${ }^{170}$ Some of the Festival pageants — Dartford, mentioned above, is an examplefocused on social and economic history, foregrounding the local and civic dimension, and in

\footnotetext{
${ }^{168}$ W. Sharp, 'Introduction', City of Nottingham Quincentenary Pageant. 169 'Aidan the Christlike': http://historicalpageants.ac.uk/pageants/1363/ (accessed 7 Mar. 2017); A Pageant of St Ethelreda [Æthelthryth]: Souvenir Programme (Ely, 1951). ${ }^{170}$ Ipswich Pageant in Christchurch Park, Celebrating the 750th Anniversary of the Incorporation of the Borough and the Festival of Britain (Ipswich, 1951); King's Lynn Charter Pageant 1204-1954 (King's Lynn, 1954).
} 
cases such as these, the importance of the medieval origins of the urban community could easily be emphasised.

However, in many places population mobility and increasing ethnic diversity made it more difficult to sustain the notion of unbroken continuity, which had been a key component of the Edwardian pageant tradition; and by the 1950s the declining power and prestige of local government meant that many post-war pageants drew on the 'civic Middle Ages' in an essentially defensive mode. At Ipswich, one scene of the pageant depicted a procession of the guilds in the time of Edward III; this contrasted with the weakened local government of the 1950s, which some local commentators mentioned in their responses to the pageant. ${ }^{171}$ Other pageants drew on the example of earlier periods of strong civic identity to promote resistance to unwelcome aspects of social change: thus at St Albans in 1953 pageant-master Swinson declared: 'I feel it is all to the good to stimulate pride in the city just now, when it is in danger of becoming just a dormitory, or a large disorganized mass. ${ }^{, 172}$ Similar comments were made in the publicity for the Guildford pageant in $1957 .{ }^{173}$ The medieval period could provide inspiration by way of local political and economic history — recall the proud boasts about local rope at Bridport in 1953 - to support the institutions and civic culture of post-war urban communities in a time of planning, centralisation and rapid economic change. However, the defensive dimension to the deployment of the Middle Ages was stronger now than ever before. In earlier pageants, the medieval had supported distinctive local identities that themselves drew strength from — and reinforced — a wider sense of national identity. This mutually supportive relationship between the local and the national was now less in evidence: the medieval roots of locality still mattered, but tended to be mobilised more reactively. As at St Albans, the aim of pageant organisers from the 1950s on was more focused on shoring up

${ }^{171}$ Ipswich Evening Star, 12 June 1951, p. 4 and 14 June 1951, p. 4.

172 Quoted in Freeman, "Splendid Display", p. 443.

${ }^{173}$ Ibid., pp. 444-5. 
an increasingly beleaguered sense of local distinctiveness in the context of national changes - social, economic, ethnic, demographic — that seemed, at least to some, to presage the dislocation of historic communities.

None of this, however, needed to get in the way of putting on an enjoyable show. Already in retreat in the late 1940s and 1950s, the reverential performance of medieval scenes in the form of a historical pageant was increasingly seen as outdated by the 1960 s and 1970s. Insofar as the pageants staged in these decades succeeded in enthusing local populations behind the re-enactment of their medieval pasts, they did so by presenting history as entertainment and ensuring a blend of humour and popular instruction. This style of engagement with the medieval past reflected what had been happening on large and small screens since the war. Big-budget cinema epics set in the medieval period ranged from Henry $V(1944)$ to Ivanhoe (1952) to The Vikings (1958), while viewers of the new ITV channel in the second half of the 1950s saw more than 140 episodes of The Adventures of Robin Hood, not to mention a number of Arthurian dramas. ${ }^{174} \mathrm{With}$ historical pageantry in decline, other forms of popular engagement with the past grew in significance. Battle re-enactment societies flourished from the 1960s onwards, often focusing their efforts on medieval subject-matter, including the Battle of Hastings and the Wars of the Roses, and non-military events were reenacted by organisations such as the Plantagenet Medieval Society. ${ }^{175}$ One event in particular - a 'Pageant to Commemorate the 900th Anniversary of the Battle of Hastings' in 1966 - which was watched by 24,000 people, was essentially a re-enactment billed as a

\footnotetext{
${ }^{174}$ Laurence Olivier (producer/director), Henry V (Two Cities Films, 1944); Pandro S. Berman (producer), Ivanhoe (Metro-Goldwyn-Mayer, 1952); Kirk Douglas (producer), The Vikings (United Artists, 1958); The Adventures of Robin Hood (1955-60): http://www.imdb.com/title/tt0047706/fullcredits/ (accessed 7 Mar. 2017); The Adventures of Sir Lancelot (1956-7): http://www.imdb.com/title/tt0048841/ (accessed 7 Mar. 2017). ${ }^{175}$ R. Samuel, Theatres of Memory, Vol. I: Past and Present in Contemporary Culture (London, 1994), 193, 270-1. See http://www.plantagenet.org.uk/ (accessed 7 Mar. 2017).
} 
historical pageant. ${ }^{176}$ At the same time, a parallel resurgence of interest in the history of 'everyday life' stimulated various embodiments of 'living history', and this kind of up-closeand-personal engagement with the past did not necessarily suit the large-scale performance and spectacle associated with historical pageantry. ${ }^{177}$ The rise of social history and 'history from below' encouraged different forms of theatrical performance of the past: an important example from this period was the community play, a type of production that was similar to the historical pageant in some respects, but which tended to focus on a single episode from the past, often involving popular rebellion and discontent. ${ }^{178}$ Thus while historical pageantry was not dead by the 1960s and 1970s, it had to compete—usually unsuccessfully—with a whole series of alternative forms of 'living history' and popular nostalgia.

\section{[LINE SPACE HERE]}

The abiding popularity but changing emphasis of the depiction of medieval history in pageants is a striking example of 'the presence of the past in British society'. ${ }^{179}$ During the first six decades of the twentieth century, historical pageantry was one of the most prominent ways in which the mass of the population engaged with history, and the medieval past held particular importance in a number of ways. The medieval period was seen as the origin of the modern church and constitution, themes which featured strongly in Edwardian and interwar pageants respectively, and also the origin of the civic community that pageants were written and organised to celebrate. In many smaller, older, provincial towns and villages, the importance of the medieval was obvious, but even in newer industrial towns and cities the

\footnotetext{
${ }^{176}$ Evening Argus, 16 Oct. 1966; Grand 1066 Pageant to Commemorate the 900th Anniversary of the Battle of Hastings (n.p., 1966).

${ }^{177}$ See L. Carter, 'Histories of the Everyday and Democratic Culture in Britain c.1918-1969' (Univ. of Cambridge Ph.D. thesis, 2017).

${ }^{178}$ See B. Kershaw, The Politics of Performance: Radical Theatre as Cultural Intervention (London, 1992), pp. 185-205.

${ }^{179}$ P. Wright, On Living in an Old Country: The National Past in Contemporary Britain (Oxford, 2009 [1985]), p. ix.
} 
writers of pageants sought to root the history of their communities in a venerated medieval past, drawing on the imagery of the 'civic Middle Ages' to emphasise their solidity and resilience in the face of economic and other challenges. Indeed, the pageant itself could be seen as a modern-day reinvention of an older medieval civic tradition, as was made evident, perhaps most notably, by the interwar and postwar performances held in association with civic weeks and industrial exhibitions. Even in the 1950s medieval history could serve a political and social purpose in the context of post-war changes that seemed to threaten the existence of the civic community. However, the medieval past now performed a less important role in the construction of both national and local identities. The experience of post-war modernity and affluence weakened the sense of popular connection with the medieval, at least insofar as that connection supported attachment to place and nation, and the lessons of the 'constitutional Middle Ages' were less apparent to audiences after 1945. People were undoubtedly still interested in medieval history, and enjoyed watching many aspects of the medieval past depicted on stage and screen, and sometimes in pageants, but the content of that past did not play the same role in the construction of collective identities. Exceptions could be found in places such as St Albans and Bury St Edmunds, where the medieval past was unavoidably inscribed in the physical fabric of the town in which the pageants were performed. By this time, however, audiences were 'consuming' the past in different ways, and the historical pageant, while never disappearing entirely, was unable to retain its position as a key means of popular engagement with the medieval period. To paraphrase Umberto Eco, people still seemed to like the Middle Ages, ${ }^{180}$ but, in England at least, the medieval had now far less to do with constructions of collective identity, whether local or national.

${ }^{180}$ Umberto Eco, Travels in Hyperreality (New York, 1986), p. 61. 
UNIVERSITY OF EDINBURGH

UNIVERSITY OF GLASGOW

UCL INSTITUTE OF EDUCATION

QUEEN's UNIVERSITY BELFAST

KING'S COLLEGE LONDON

KING's COLLEGE LONDON
Angela Bartie

LINDA FLEMING

MARK FREEMAN

Tom Hulme

Alexander Hutton

PAUL READMAN 